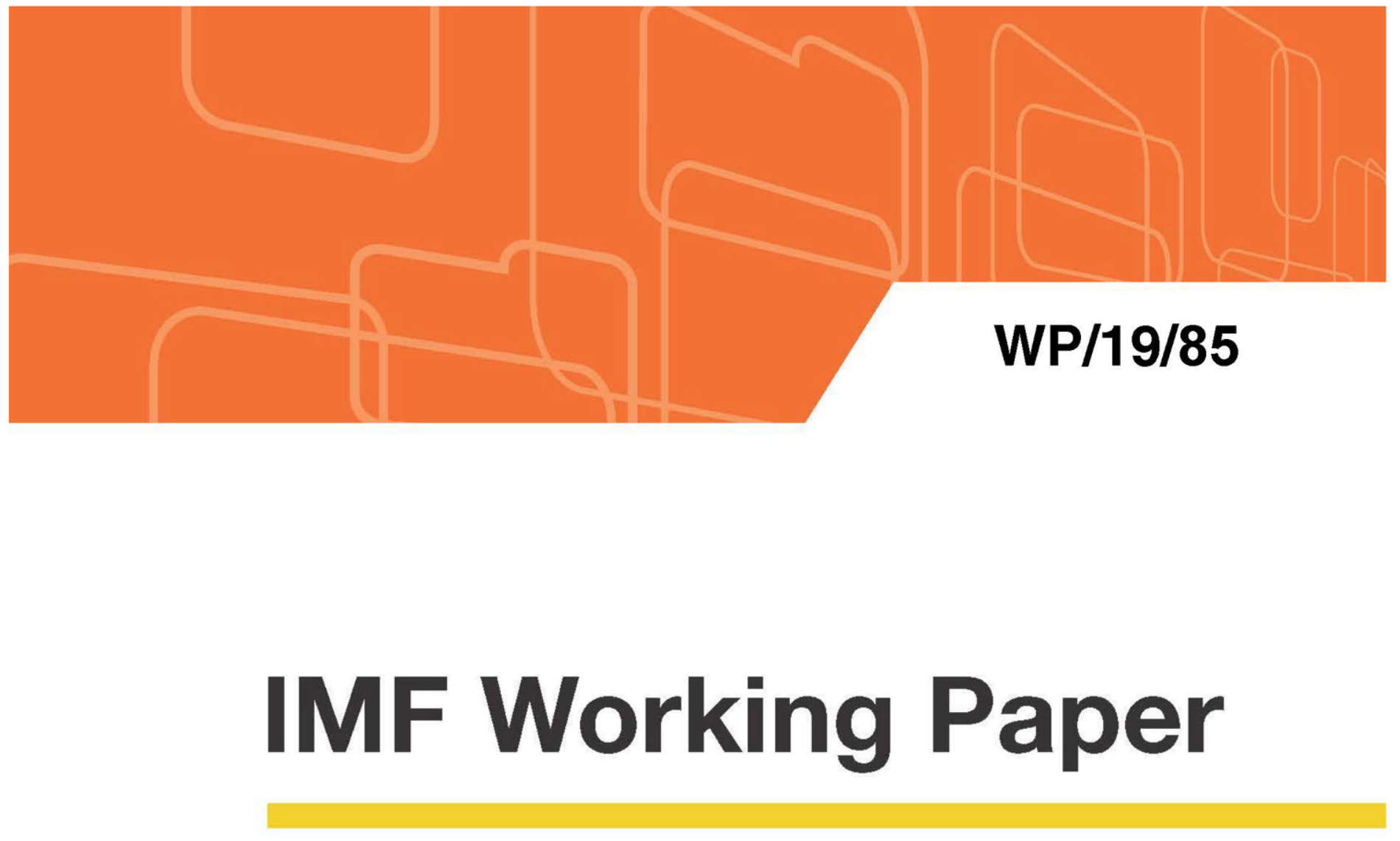

\title{
Capital Flows: The Role of Bank and Nonbank Balance Sheets
}

by Yuko Hashimoto and Signe Krogstrup

IMF Working Papers describe research in progress by the author(s) and are published to elicit comments and to encourage debate. The views expressed in IMF Working Papers are those of the author(s) and do not necessarily represent the views of the IMF, its Executive Board, or IMF management. 


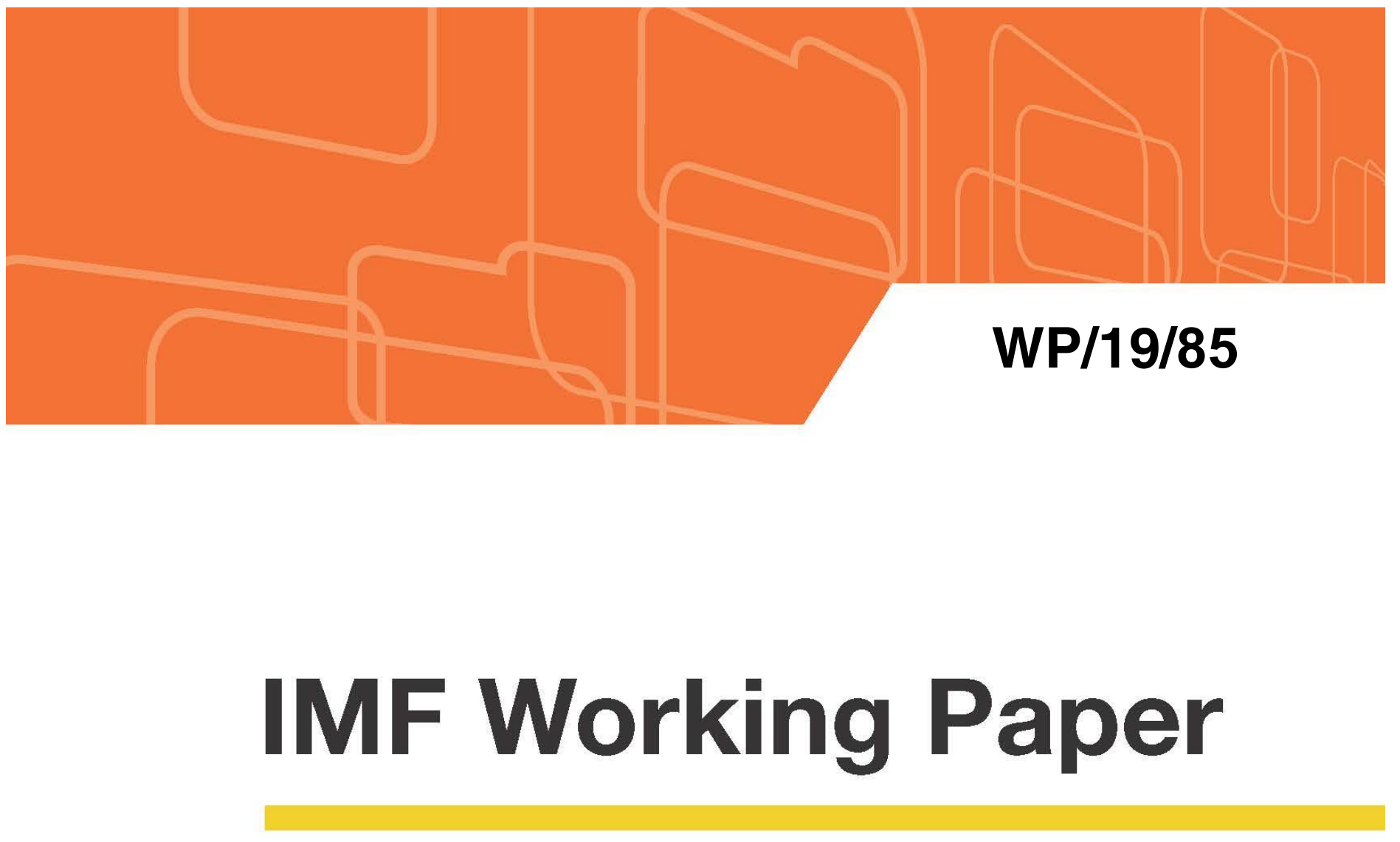

\section{Capital Flows: The Role of Bank and Nonbank Balance Sheets}

by Yuko Hashimoto and Signe Krogstrup

IMF Working Papers describe research in progress by the author(s) and are published to elicit comments and to encourage debate. The views expressed in IMF Working Papers are those of the author(s) and do not necessarily represent the views of the IMF, its Executive Board, or IMF management.

I N T E R N A T I O N A L M O N E T A R Y F U N D 


\title{
IMF Working Paper
}

\author{
Research Department
}

\section{Capital Flows: The Role of Bank and Nonbank Balance Sheets}

\author{
Prepared by Yuko Hashimoto and Signe Krogstrup ${ }^{1}$ \\ Authorized for distribution by Signe Krogstrup
}

April 2019

\begin{abstract}
IMF Working Papers describe research in progress by the author(s) and are published to elicit comments and to encourage debate. The views expressed in IMF Working Papers are those of the author(s) and do not necessarily represent the views of the IMF, its Executive Board, or IMF management.
\end{abstract}

\begin{abstract}
This paper assesses the role of bank and nonbank financial institutions' balance sheet foreign exposures and risk management practices in driving capital flow responses to global risk. Using a unique and previously unexplored dataset on domestic and cross border balance sheet positions of financial institutions collected by the IMF, we show that the response of overall capital flows to global risk shocks is associated with the on-balance sheet foreign exposures of nonbanks, but not with that of banks. A possible interpretation is that risk-averse and dynamically optimizing nonbanks reduce their foreign risk exposure when global risk perceptions increase, leading to capital flows, while banks tend to be hedged against these risks off balance sheet. In advanced countries, the findings suggest that nonbank portfolio adjustment to changing risk conditions may take place through derivatives transactions with banks, the hedging practices of which trigger bank related capital flows rather than portfolio flows.
\end{abstract}

\section{JEL Classification Numbers: F3, G1, G2}

Keywords: foreign exposure; global factor, risk aversion, global financial crisis; forward contract; capital flow management measures; macro prudential policy

\section{Authors'e-mail addresses: YHashimoto@imf.org; SKrogstrup@imf.org}

\footnotetext{
${ }^{1}$ We are grateful for comments from Yan Carriere-Swallow, Gaston Gelos, Nicolas Magud, Claudio Raddatz, Cedric Tille, Vina Nguyen, Seng Guan Toh, Yevgeniya Korniyenko, participants at the IMF Research Department conference on "Too Many Objectives or Too Few Instruments? Economic Policy Challenges Ten Years After the Crisis," the IMF RES-MFD and STA seminars, and the Bank of Japan seminar. Excellent research assistance was provided by Wenjie Li and Xiaoxiao Zhang. We would also like to thank James Chan, Marcelo Dinenzon, Thomas Elkjaer, Justin Matz, Giovanni Ugazio, and Xiuzhen Zhao for discussions on the data.
} 


\section{Contents}

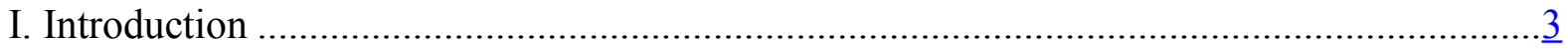

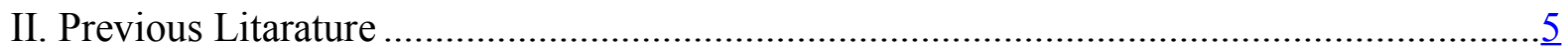

III. The SRF Data Set...................................................................................................

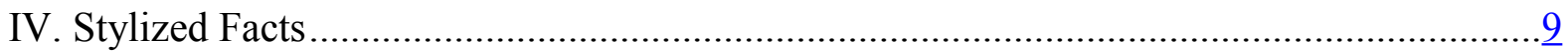

A. Most Countries Have Bank-Dominated Financial Systems.................................. 9

B. Countries with Large Financial Sectors Have Larger Nonbank Sectors..................10 C. Countries with Large Nonbank Sectors Tend to be Net Long in Foreign Exposure.

V. The Link Between Capital Flows and Net Foreign Exposures ......................................12

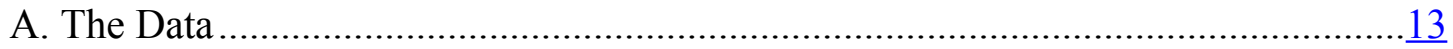

B. Global Factors in Capital Flows and Domestic Financial Institutional Structure... 14

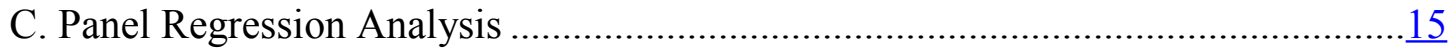

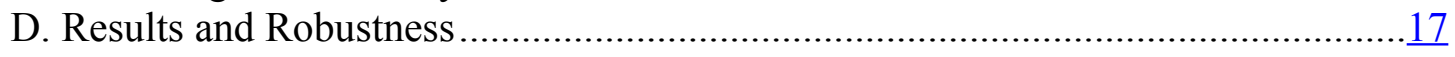

VI. An Interpretation: Nonbank Risk Management Practices and Flows.............................20

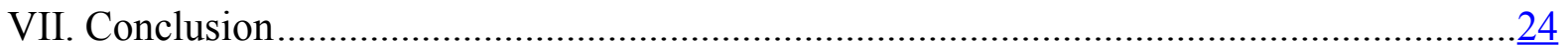

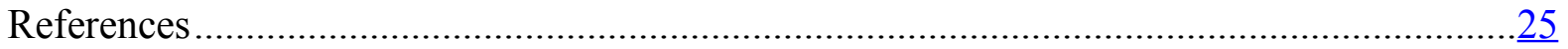

Appendix

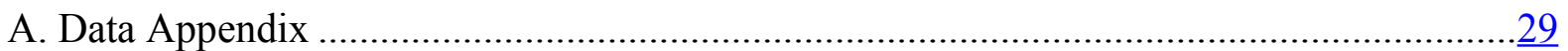

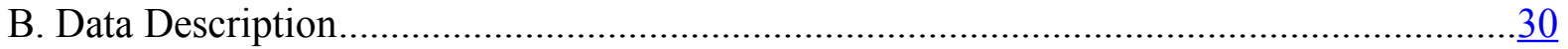

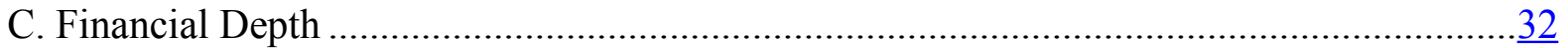

D. Net Foreign Exposure by Financial Institutions ........................................................33

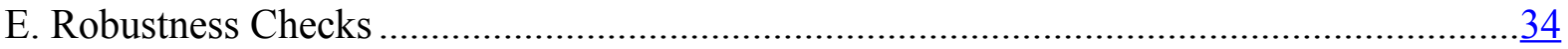




\section{INTRODUCTION}

The past decades have witnessed large swings in international capital flows, notably in connection with the global financial crisis (GFC). The role of global financial factors and risk conditions in driving these flows is well established (Forbes and Warnock 2012; Passari and Rey 2015; Bruno and Shin 2017; IMF 2013, 2016a, 2017). However, some countries experience more capital flow volatility than others due to global factors (Goldberg and Krogstrup 2018), and this cross-country variation is less well understood. Capital flow volatility in turn affects macroeconomic performance and financial stability of individual countries, sometimes to an extent that elicits policy responses (Cerutti et al. 2014). Understanding the drivers of capital flow sensitivity to global financial factors can help inform the design of such policies.

This paper focuses on the role of financial institutions' balance sheets and portfolio and risk management practices in driving the response of capital flows to global risk conditions. Financial institutions intermediate a large share of cross border investments and do so with a view to optimizing their overall portfolio and performance while managing risks. Exposures to cross border risks are often managed dynamically, by maximizing risk adjusted returns or minimizing expected losses in response to changing market conditions. A specific method is using a value-at-risk (VAR) constraint (Adrian and Shin 2012). By implication of such risk management strategies, financial institutions will respond, in real time, to increasing perceived risks of foreign exposures by reducing these exposures (Krogstrup and Tille 2018). Tightening global risk conditions thus translate into adjustments in financial institutions' foreign assets and liabilities, and hence, into capital flows.

Regulation in the form of risk sensitive capital requirements for banks can further accentuate their risk sensitive portfolio management, and bank balance sheet characteristics have been found relevant for driving bank-intermediated cross border flows. Empirically, cross border bank credit flows are particularly sensitive to global factors. Milesi-Ferretti and Tille (2011) show that observed capital flow reversals during the GFC were mainly reflected in bank credit flows (see also Brookings 2012). The previous literature has explored banks' balance sheets and portfolio and risk management behavior in driving the sensitivity of bank credit flows to global factors. Studies have linked the responsiveness of bank flows to global bank portfolio adjustments, access to funding, foreign currency funding exposures, balance sheet capacity, and leverage (Milesi-Ferretti and Tille 2011; Brookings 2012; Krogstrup and Tille 2018, IMF GFSR April 2010, Cetorelli and Goldberg 2011, 2012, Bruno and Shin 2015a).

In contrast, the literature is scarce on the role of nonbank financial institutions in driving capital flow responses to global risk factors. ${ }^{2}$ This is despite the fact that nonbanks, such as pension and insurance funds, investment funds and asset managers, hold sizeable cross border positions. They are therefore also likely to adjust their portfolio risk exposures when

\footnotetext{
${ }^{2}$ IMF (2016b) provides a good summary of policy implications related to emerging nonbank activities.
} 
perceived foreign risks increase. Data on nonbank financial institutions' capital flows are scarce, however, which has hampered empirical assessment of the role of nonbanks in driving flow responses to global risk conditions.

In this paper, we present novel evidence on the role of nonbank financial institutions as drivers of the capital flow response to global risk. Specifically, we shed new light on the role of nonbank financial institutions' foreign risks exposures. We base the evidence on a previously unexplored dataset on aggregate bank and nonbank balance sheets for a set of advanced and emerging market countries. The IMF's Standardized Report Form (SRF) data is unique in providing a balance sheet decomposition between domestic and external positions of a country's resident banks as well as nonbank financial institutions. The dataset is sufficiently rich to investigate associations between bank and nonbank balance sheet features and the sensitivity of capital flows to global factors.

We focus on net foreign exposures in resident bank and nonbank financial institutions' balance sheets. Using the SRF dataset and standard panel regression techniques, we document a statistically significant association between nonbank financial institutions' foreign exposures (defined as the degree to which nonbanks are net long in foreign assets) and a country's sensitivity of capital flows to global risk factors, as captured by the VIX. For the advanced economies in the dataset, the association is also significant when considering only bank-related capital flows, while this is not the case for the emerging market sample. In contrast, we do not find a significant association between the response of cross border capital flows to global risk factors and the on-balance sheet exposures of banks.

The findings are consistent with the hypothesis that nonbanks respond to global risk factors by adjusting their foreign exposures dynamically, leading to capital flows. In advanced countries, moreover, the finding that bank related flows respond to nonbank exposures is consistent with typical hedging practices by nonbanks through derivatives transactions. Specifically, in response to short-term fluctuations in risks, nonbanks often adjust foreign currency risks off balance sheet through derivatives contracts with their correspondent bank. ${ }^{3}$ Banks provide OTC foreign currency forwards and swaps to nonbank clients on demand at market rates, and in turn hedge these positions in cross border interbank markets, earning a spread or a fee but not taking on any additional risks or exposures. Banks' hedging of their FX derivatives book in the interbank markets is on-balance sheet and therefore recorded as bank credit-related capital flows. But the flows are driven by the portfolio risk management needs of the banks' nonbank clients, and not by the banks per se. This bank-nonbank nexus as a driver of capital flows is less well understood, mainly due to lack of data, but could be

\footnotetext{
${ }^{3}$ Denmark's case during the currency pressure in early 2015 suggests that banks may be responding to and hedging their customer demands for FX derivatives when changing cross border positions, without changing their own total exposures. (Danmark's Nationalbank 2015). Shin (2012) points to European banks' use of funds through global banks in US markets. Other literature that point evidence of banks and nonbanks interactions more broadly include FSB (2018) and Borio et al. (2017).
} 
key in driving the composition of the capital flow response to global risk factors. ${ }^{4}$ As additional support for this conjecture, we present two case studies of Denmark and Korea where bank flows have been driven by nonbank portfolio adjustments through derivatives positions, rather than reflecting the banks' own portfolio management behavior.

The findings have important policy implications. Nonbanks' foreign exposures and risk management practices may be significant drivers of capital flows, even if the resulting flows are observed primarily in bank credit flows. In countries where capital flow volatility causes disruptive foreign exchange market conditions and where capital flow management measures are considered a possible tool for managing volatility, the perimeter of such tools could be extended to include foreign exposures and risk management practices of nonbank financial institutions, when these tend to have greater exposures to foreign investments or funding. Moreover, the study points to significant cross-country heterogeneity. Bank-nonbank institutional relations are country specific, and policy responses would have to be designed within the context of such country specific features. More work to tease out country specific links between capital flows and bank and nonbanks foreign exposures would be desirable for informing the design of policy measures.

The paper is structured as follows. The next section briefly reviews the previous literature. Section III presents the SRF dataset, and Section IV presents some key stylized facts on the bank-nonbank mix across countries. In Section V, we investigate the relationship between the response of capital flows to global risk on the one hand, and bank and nonbank balance sheet exposures to foreign risks on the other. We offer our interpretation of the findings and present supporting evidence in the form of case studies in Section VI. The last section concludes, and the appendix contains supporting material.

\section{Previous Literature}

Financial intermediaries manage their assets and liabilities to optimize some function of expected returns and risks over a given horizon and given mandates, subject to various institution-specific constraints and financial frictions. The mix of financial institutions intermediating funds in an economy can hence have real economic effects (Bernanke and Gertler 1989, Kiyotaki and Moore 1997, Adrian and Shin 2010, Adrian and Boyarchenko 2013 and many others).

A nascent literature analyzes the role of specific financial intermediaries, their portfolio optimization behaviors and the constraints they face, in the transmission of cross border financial shocks. This literature has mainly focused on the role of banks, for which relatively complete portfolio data are available across countries. Levchenko and Mauro (2007) and Milesi-Ferretti and Tille (2011) show that bank intermediated capital flows are more prone to

\footnotetext{
${ }^{4}$ The literature on bank-nonbank relations and cross-border positions include, for example, Abad et al. (2017), FSB (2018), and Borio et al (2017).
} 
sudden stops than other types of flows and were the main drivers of the great retrenchment during the global financial crisis. Cetorelli and Goldberg $(2011,2012)$ illustrate how the internal capital markets of global banks contribute to the international propagation of shocks. Bruno and Shin (2015b) look at how funding conditions of center countries is transmitted by global banks to local bank funding conditions in a model of global banking. Krogstrup and Tille (2018) focus on local bank balance sheet characteristics and show how they affect local banks' foreign funding demand, and in turn, the responsiveness of bank intermediated capital flows to global risk conditions. For aggregate bank balance sheet data in a sample of European countries outside the euro area, they show that the response of cross border bank funding flows to global risk conditions depends on the pre-existing balance sheet exposure of banks to global risks. Other contributions to the literature consider how different behaviors or constraints placed on financial institutions, such as leverage constraints, affect the balance sheet response of these institutions to global risk factors (Miranda-Agrippino and Rey 2018, Devereux and Yetman 2010). None of these contributions consider the possible role of banknonbank interactions and the fact that many bank balance sheet operations happen on behalf of nonbank clients.

Some recent contributions consider the role played by other types of financial intermediaries. Cerutti, Claessens and Puy (2015) investigate the link between capital flow sensitivity to global factors and the types of foreign investors holding the foreign liabilities in a panel of emerging markets. A central finding is that a country's mix of foreign investor types matters for its capital flow sensitivity to global factors. They measure the mix of types of foreign investors indirectly, however, as cross country comparable data on this breakdown is not available. IMF (2014) focuses on a country's sensitivity of asset prices to global factors and similarly looks at the role that the mix of foreign investors plays in this sensitivity. They also investigate the role of domestic financial institutional depth and find it to matter, suggesting that more developed local financial markets better absorb the effects of global financial shocks. A key finding is that a larger size of pension funds in the economy reduces the response of domestic asset prices and the exchange rate to global factors.

These studies are suggestive of a role for the size and mix of domestic financial institutions in the response of capital flows to global factors, although the mechanisms behind the findings are not clear.

This paper looks at a specific mechanism for why capital flows respond to global risk, namely risk management practices and the drive to reduce foreign exposures when global risk conditions increase. It focuses on the relative importance of bank vs nonbank exposures and risk management responses in driving these responses. This line of research has previously been hampered by the lack of available comprehensive data on the balance sheets of nonbank financial institutions like the BIS banking statistics. We make use of a new dataset that allows an assessment. 


\section{THE SRF DATA SET}

The balance sheet data used in this paper are based on the IMF's Standardized Report Form (the SRF). Using the SRF, some IMF member countries' report, on a voluntary basis, aggregate monetary and financial balance sheet data in a cross country comparable format. The dataset provides balance sheet (stock) positions for banks and nonbank financial institutions, and its structure is illustrated in Figure 1. Balance sheet positions are provided separately for assets and liabilities, disaggregated into three sub-categories of the financial sector: the central bank, other depository corporations (ODCs - henceforth referred to as banks) and other financial institutions (OFCs - henceforth referred to as nonbanks). The bank category includes commercial banks, credit unions, and other deposit-taking corporations. Nonbanks are financial institutions which are not categorized as banks (or ODCs) and include institutional investors such as pension and insurance funds, mutual funds and other financial institutions. ${ }^{5,6}$

A key feature relevant for our line of inquiry is that assets and liabilities are further divided by domestic and external positions. External positions are defined as positions with foreign counterparties. As shown in Figure 1, the difference between external positions on the asset side (claims on nonresidents) and external positions on the liability side (liabilities to nonresidents) is the net external position of financial institutions. All positions are available by financial instruments. The specific currency denomination of external positions is unfortunately not available. Both ODC (bank) and OFC (nonbank) data are consolidated within the sector.

Figure 1: SRF Domestic and Foreign Positions ${ }^{7}$

\begin{tabular}{|c|c|c|c|c|c|}
\hline \multicolumn{3}{|c|}{ Banks } & \multicolumn{3}{|c|}{ Non-Banks } \\
\hline & Claims & Liabilities & & Claims & Liabilities \\
\hline Residents & Domestic assets & Domestic liabilities & Residents & Domestic assets & Domestic liabilities \\
\hline Non-resident & Foreign assets & Foreign liabilities & Non-resident & Foreign assets & Foreign liabilities \\
\hline & NFA & $=\mathrm{FA}-\mathrm{FL}$ & & NFA & $\mathrm{B}=\mathrm{FA}-\mathrm{FL}$ \\
\hline
\end{tabular}

\footnotetext{
${ }^{5}$ Classification of financial institutions follows Monetary and Financial Statistics manual and Compilation Guide (2016). Institutional framework consists from financial corporations (FCs) and other financial corporations (OFCs). Financial corporations (FCs) are divided into two sub categories, central banks (CBs) and other depository corporations (ODCs). ${ }^{6}$ According to Monetary and Financial Statistics Manual and Compilation Guide (2016), banks (other depository corporations) include deposit-taking corporations except the central bank and money-market funds (MMFs). Nonbanks (other financial corporations) include non-MMF investment funds, other financial intermediaries except insurance corporations and pension funds (ICPF), financial auxiliaries, captive financial institutions and money lenders, insurance corporations, and pension funds.

${ }^{7}$ Thanks to Nicolas Magud (2018) for sharing this illustration.
} 
The data is available in different frequencies for different countries (monthly or quarterly), and availability differs across sub-categories, with data on banks available from December 2001 for most countries, whereas data for nonbanks becomes available only later in many countries. To maximize the coverage of the data sample we consider, we focus on data in quarterly frequency and include only countries and sample periods with good coverage of nonbanks. This leaves us with a sample of 24 countries, including three Advanced Economies (AEs), namely the US, Japan and Sweden, and 21 Emerging Markets (EMs). The sample is described in more detail in Appendix Table A1. ${ }^{8}$ Table 1 below provides selected summary statistics for some of the key series, divided on AEs and EMs, for comparability based on the subset of eight countries where time series data availability fully covers the period from 2001Q4 to 2017Q4. The table shows that bank and nonbank balance sheet size has generally expanded over time, except for temporary contractions in balance sheet size for some AEs during the global financial crisis period.

\footnotetext{
${ }^{8}$ There are several more countries that provide both banks and nonbanks data. However, we excluded these countries because their institutional coverage (banks and/or nonbanks) deviates largely from the institutional classification of the Monetary and Financial Statistics manual and Compilation Guide (2016). Any deviations from the compilation methodology are documented in the IFS World and Country Notes Yearbook. http://data.imf.org/?sk=4C514D48-B6BA49ED-8AB9-52B0C1A0179B\&sId=1450715373824.
} 
Table 1. Selected Summary Statistics of Balance Sheets, GDP Share

\begin{tabular}{|c|c|c|c|c|c|c|c|c|c|c|}
\hline & \multicolumn{5}{|c|}{$\mathrm{AE}$} & \multicolumn{5}{|c|}{ EM } \\
\hline & Mean & Max & Min & Std. Dev & Obs & Mean & Max & Min & Std. Dev & Obs \\
\hline \multicolumn{11}{|l|}{ Before crisis } \\
\hline Banks size & 4.020 & 6.068 & 2.132 & 1.497 & 66 & 1.765 & 4.009 & 0.147 & 1.089 & 110 \\
\hline Nonbank size & 4.671 & 6.127 & 2.385 & 1.166 & 66 & 0.881 & 3.714 & 0.012 & 1.158 & 110 \\
\hline Bank foreign transaction size & 0.494 & 1.191 & 0.140 & 0.305 & 66 & 0.091 & 0.212 & 0.014 & 0.049 & 110 \\
\hline Nonbank foreign transaction size & 0.423 & 0.789 & 0.188 & 0.175 & 66 & 0.057 & 0.214 & 0.000 & 0.069 & 110 \\
\hline Bank claims on nonresidents & 0.245 & 0.584 & 0.074 & 0.136 & 66 & 0.049 & 0.144 & 0.006 & 0.037 & 110 \\
\hline Bank liabilities to nonresidents & 0.250 & 0.607 & 0.066 & 0.179 & 66 & 0.042 & 0.113 & 0.007 & 0.021 & 110 \\
\hline Nonbank claims on nonresidents & 0.325 & 0.661 & 0.120 & 0.161 & 66 & 0.054 & 0.198 & 0.000 & 0.068 & 110 \\
\hline Nonbank liabilities to nonresidents & 0.098 & 0.229 & 0.013 & 0.052 & 66 & 0.003 & 0.017 & 0.000 & 0.004 & 110 \\
\hline \multicolumn{11}{|l|}{ crisis } \\
\hline Banks size & 4.666 & 6.368 & 2.544 & 1.474 & 24 & 1.826 & 3.125 & 0.151 & 0.977 & 40 \\
\hline Nonbank size & 4.958 & 6.919 & 2.974 & 1.256 & 24 & 1.148 & 3.667 & 0.055 & 1.245 & 40 \\
\hline Bank foreign transaction size & 0.727 & 1.490 & 0.253 & 0.460 & 24 & 0.128 & 0.413 & 0.011 & 0.108 & 40 \\
\hline Nonbank foreign transaction size & 0.548 & 0.810 & 0.353 & 0.163 & 24 & 0.068 & 0.240 & 0.000 & 0.083 & 40 \\
\hline Bank claims on nonresidents & 0.389 & 0.738 & 0.124 & 0.215 & 24 & 0.062 & 0.224 & 0.006 & 0.063 & 40 \\
\hline Bank liabilities to nonresidents & 0.338 & 0.751 & 0.126 & 0.254 & 24 & 0.065 & 0.189 & 0.006 & 0.046 & 40 \\
\hline Nonbank claims on nonresidents & 0.403 & 0.654 & 0.194 & 0.160 & 24 & 0.062 & 0.239 & 0.000 & 0.080 & 40 \\
\hline Nonbank liabilities to nonresidents & 0.145 & 0.232 & 0.056 & 0.064 & 24 & 0.006 & 0.028 & 0.000 & 0.010 & 40 \\
\hline \multicolumn{11}{|l|}{ after crisis } \\
\hline Banks size & 4.937 & 7.320 & 2.314 & 1.870 & 78 & 1.926 & 3.936 & 0.136 & 1.116 & 130 \\
\hline Nonbank size & 5.588 & 7.385 & 3.611 & 1.211 & 78 & 1.286 & 4.075 & 0.067 & 1.360 & 130 \\
\hline Bank foreign transaction size & 0.761 & 1.388 & 0.243 & 0.415 & 78 & 0.111 & 0.344 & 0.006 & 0.081 & 130 \\
\hline Nonbank foreign transaction size & 0.629 & 1.169 & 0.373 & 0.239 & 78 & 0.093 & 0.350 & 0.000 & 0.119 & 130 \\
\hline Bank claims on nonresidents & 0.430 & 0.784 & 0.116 & 0.238 & 78 & 0.050 & 0.187 & 0.004 & 0.048 & 130 \\
\hline Bank liabilities to nonresidents & 0.331 & 0.643 & 0.126 & 0.182 & 78 & 0.061 & 0.158 & 0.002 & 0.037 & 130 \\
\hline Nonbank claims on nonresidents & 0.491 & 1.004 & 0.247 & 0.226 & 78 & 0.087 & 0.347 & 0.000 & 0.115 & 130 \\
\hline Nonbank liabilities to nonresidents & 0.138 & 0.210 & 0.053 & 0.040 & 78 & 0.006 & 0.035 & 0.000 & 0.009 & 130 \\
\hline
\end{tabular}

Note: Descriptive statistics of country groups are based on unweighted means, implying that a mean of a variable of each of the country group is based on a sum of the variable-GDP share. $\left(\sum \frac{X i}{G D P i}\right)$. Countries included are US, Japan, Sweden (AEs), Brazil, Chile, El Salvador, Honduras, and South Africa (EMs), whose bank as well as nonbank time series data availability fully covers the period from 2001Q4 to 2017Q4. Before crisis data are an average of the sample period from 2001Q4 to 2007Q2, crisis period between 2007Q3 and 2009Q2, and After crisis is a period of 2009Q3-2017Q4.

\section{STYLized FACTS}

The SRF dataset offers an interesting view on the variation in domestic financial institutional structure across countries. We illustrate some of this variation in three stylized facts, pertaining to the relative roles of banks vs. nonbanks in (i) countries' domestic and external balance sheet; (ii) financial depth; and (iii) foreign exposures in financial institutions' balance sheets.

\section{A. Most Countries Have Bank-Dominated Financial Systems}

Figure 2 illustrates cross-country differences in the relative size of banks and nonbanks in the financial system. The blue bars reflect the share of financial institutions' total balance sheet that is comprised of banks. The bank balance sheet share exceeds 0.6 in most countries, with large variation across countries. Advanced economies generally have less bank-dominated 
systems. At one extreme are the United States and South Africa, whose bank shares are below $50 \% .{ }^{9}$ At the other extreme, banks in some EMs comprise more than $80 \%$ of financial institutions' total balance sheet.

The green bars show that banks also tend to have a higher share of financial institutions' external balance sheet. This could reflect the use by banks of foreign funding and lending through global banking networks (Cetorelli and Goldberg 2011), whereas nonbanks, such as pension funds and insurance funds, tend to have more domestic liabilities. In some countries, however, bank shares are lower in the external than domestic sector, including Chile, Colombia and Thailand.

Figure 2. Bank Share of Total Financial Institutions

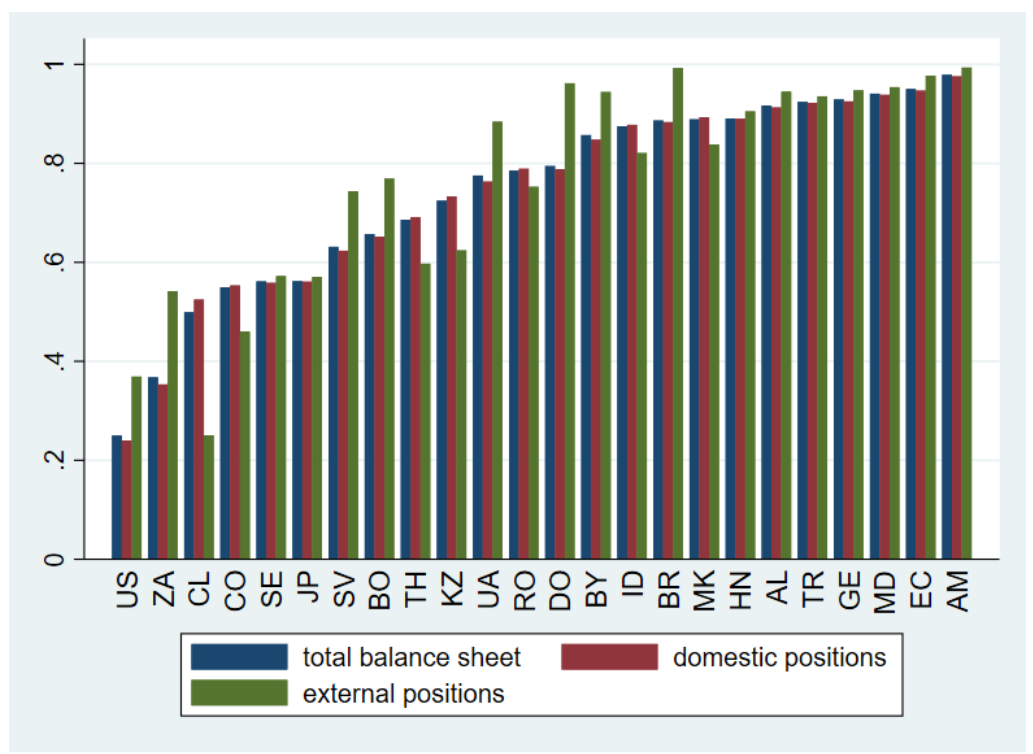

\begin{abstract}
Note: the chart is based on the average of the most recent five-year observations. Countries are sorted by share of banks in total assets. Bank share for total, domestic, and external, are calculated as follows: Bank total share out of total financial institutions $=($ Bank total assets + Bank total liabilities $) /($ Bank total assets + Bank total liabilities + Nonbank total assets + Nonbank total liabilities); Bank domestic share out of total financial institutions $=($ Bank domestic assets + Bank domestic liabilities) / (Bank domestic assets + Bank domestic liabilities + Nonbank domestic assets + Nonbank domestic liabilities); Bank external share out of total financial institutions $=($ Bank external assets + Bank external liabilities) / (Bank external assets + Bank external liabilities + Nonbank external assets + Nonbank external liabilities). All bank balance sheet data are from the SRF dataset. The bar chart therefore illustrates banks' share in the market, and one minus the bar measures the nonbank share.
\end{abstract}

\title{
B. Countries with Large Financial Sectors Have Larger Nonbank Sectors
}

Figure 3 illustrates a relationship between the total size of the financial sector, or financial depth, and the bank share in the financial system. We define financial depth as financial institutions' balance sheet as a share GDP. ${ }^{10}$ The Figure shows a clear association between

\footnotetext{
${ }^{9}$ Similar findings in, for example, FSB (2018).

${ }^{10}$ Financial depth based on domestic and external positions, as well as relationships between these financial depth measures and the bank share are shown in Appendix C. IMF (2015) discusses that "nonbanks \& private financial markets increase in size relative to the banking system" in Figure 1 and proposes several indicators as measures of financial development.
} 
this measure of financial depth and banks' share in the total financial balance sheet: The greater the financial depth, the smaller is the bank share, or the greater is the nonbank share of the total financial system. The negative association is steeper and equally significant within the EM sample alone. This may point to a tendency for financial development to be associated with a more diversified set of financial institutions. ${ }^{11}$

Figure 3. Financial Depth

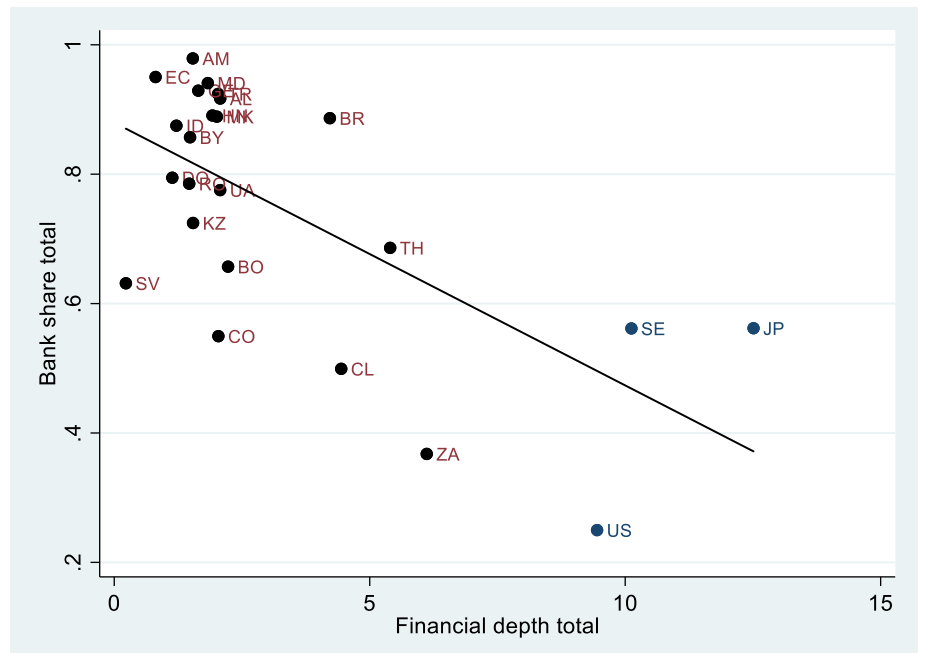

\begin{abstract}
Note: The chart is based on the average of the most recent five years of observations. Financial depth is based on total positions and calculated as follows: Financial depth for total $=($ Bank total assets + Bank total liabilities + Nonbank total assets + Nonbank total liabilities) / GDP. Bank share total is as the one used in Figure 2. The relationship between financial depth based on domestic positions and external positions individually and the bank share exhibit similar patterns (not shown).

Source: The SRF dataset.
\end{abstract}

\title{
C. Countries with Large Nonbank Sectors Tend to be Net Long in Foreign Exposure
}

As our focus is on the portfolio risk management practices of banks and nonbanks and how this translates into capital flows when global risk conditions change, we consider the net foreign exposure of banks and nonbanks by country in the two panels in Figure 4, plotted against the country's share of banks in the financial sector. Net foreign exposure is measured as the difference between external assets and external liabilities divided by total assets. This net exposure measure can be interpreted as a proxy for financial institutions' on-balance sheet exposure to foreign currency risk (as in Krogstrup and Tille 2018) as well as capturing foreign credit risk more generally. ${ }^{12}$ It does not account for the part of this risk which is hedged off-balance sheet, for example through currency forwards or futures. The measure of

\footnotetext{
${ }^{11}$ Our sample countries do not include financial centers. It is therefore less likely that high, bank-related, external positions boost financial depth without actual development in the domestic financial system.

${ }^{12}$ The measure could also reflect maturity risk related to foreign assets and liabilities, if there are systematic differences between the maturity of foreign assets and liabilities. This would be likely if foreign assets tend to be held by nonbanks with longer investment horizons, such as pension and insurance funds, and foreign funding reflects interbank funding, which tend to be of a shorter horizon. We cannot observe maturity in the SRF data.
} 
net exposure reflects a subset of a country's total net foreign assets that takes into account net foreign assets held by financial institutions and dividing these by total balance sheet positions of these institutions. We control for total net foreign assets in our regressions below.

Comparing the two panels in Figure 4 shows that there is less variation in banks' foreign exposures than in nonbank foreign exposures across countries. Banks tend to be more balanced in terms of foreign exposures on balance sheet. Moreover, there is a clear negative relationship between the bank share of the financial system and nonbanks' net long position, whereas this is not as clear in the case of banks' net long position. This stylized fact suggests that well developed financial systems with larger shares and hence size of nonbank financial institutions also tend to have nonbanks that hold more foreign assets than foreign funding, whereas nonbanks in bank dominated systems tend to have more foreign funding than foreign assets. In the next section where we assess the role played by the foreign exposure in driving capital flow responses to global risk, we control for bank share.

Figure 4. Net Foreign Exposure by Domestic Financial Institutions
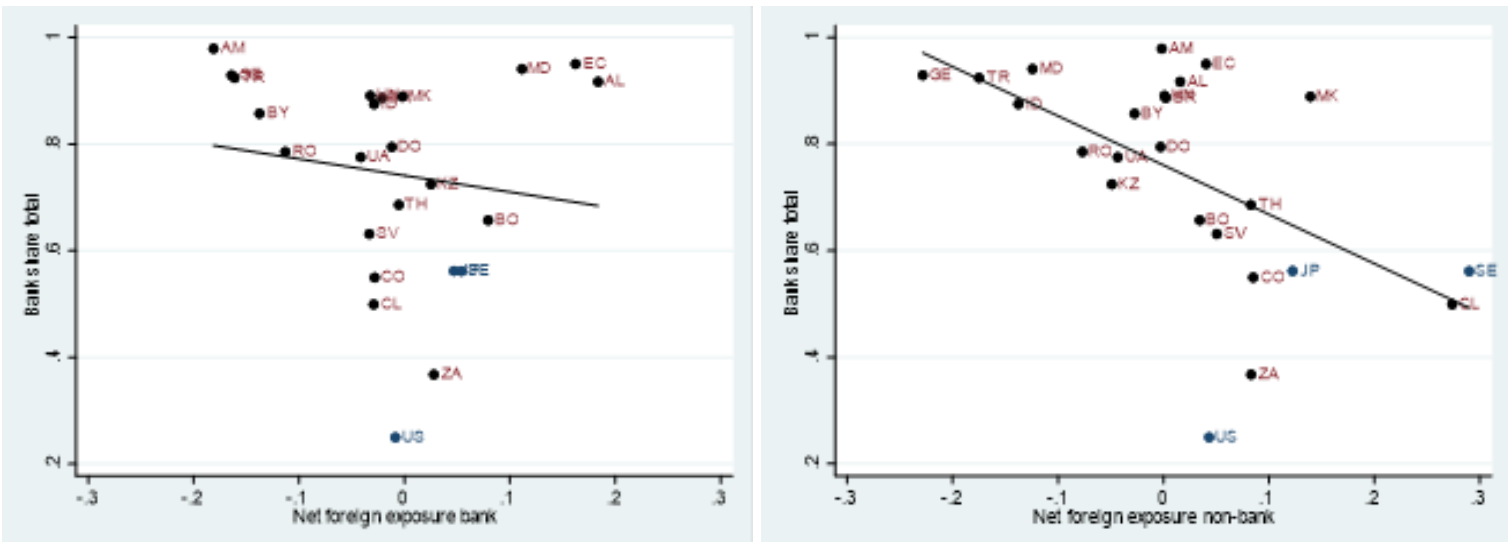

\begin{abstract}
Note: charts are based on the average of the most recent five years of observations. The net foreign exposure is calculated for either of banks and nonbanks and measured as followed: Net exposure for banks $=($ Banks external assets - Banks external liabilities) / Banks total assets; Net exposure for nonbanks = (Nonbanks external assets Nonbanks external liabilities) / Nonbanks total assets. Bank share total is the one used in Figure 2.

Source: The SRF dataset.
\end{abstract}

\title{
V. The Link Between Capital Flows ANd Net Foreign Exposures
}

We now investigate whether there is a link between observed balance sheet exposures of banks and nonbank financial institutions and the response of countries' capital flows to global risk factors.

Capital flows are expressions of active changes in the balance sheet composition of the actors participating in cross border trade in assets. In this perspective, financial institutions' portfolio optimization and risk management behavior have a first-order effect on capital flows. Krogstrup and Tille (2018) illustrate how portfolio responses to global risk conditions affect risk averse financial institutions' demand for foreign assets and funding. Their focus is 
on foreign currency denominated funding, but the mechanisms can be interpreted as applying to foreign assets and liabilities more broadly. Specifically, if a financial institution is net long in foreign assets (implying that it has more foreign assets than foreign liabilities), and hence net long in global risks, it will tend to repatriate foreign assets, or increase foreign funding, when global risk perceptions or aversion increases. Conversely, if the financial institution is net short in foreign assets (implying that it has more foreign liabilities than foreign assets), a reduction in risk exposure implies a shedding of foreign funding, or a purchase of foreign assets, and hence a capital outflow. The net exposure to foreign risk in a financial institution's balance sheet therefore can drive the sign of the capital flow response to changes in global risk conditions.

Below, we investigate whether foreign balance sheet exposures of banks and nonbanks are significantly associated with the response of a country's capital flows to global risk factors in the data.

\section{A. The Data}

Data on balance sheet exposures are taken from the SRF database described in Section III. Data on capital flows are from the Financial Flows Analytics database of the IMF. Since we are interested in the response of private capital flows to global risk factors and want to exclude any possible off-setting official flows, for example due to FX interventions, we follow Lane and Milesi-Ferretti (2011), Alfaro et al. (2014), and Scheubel et al. (2018) and focus on non-official flows.

Most studies in the literature deflate capital flows by GDP to make them comparable across countries and time. We proceed differently, as we are taking an institutional and portfolio balance perspective. What matters for the size of flows responding to risk conditions from a portfolio rebalancing perspective is the size of the portfolio being adjusted, and not the size of the economy in which the portfolio is embedded. We do not have data on the total balance sheet of the country, however, and we instead scale capital flows by the equivalently measured privately held international investment positions from the IMF. ${ }^{13}$ Specifically, we scale gross outflows (i.e. active adjustments in resident's holdings of foreign assets) by gross private foreign assets, gross private inflows (foreign residents' adjustments of foreign liabilities) by gross private foreign liabilities, and we scale net capital inflows by the average of gross private inflows and outflows. ${ }^{14}$

The response of capital flows to global factors is not directly comparable across countries with different exchange rate regimes, as countries with flexible exchange rate regimes will tend to see an exchange rate adjustment in response to incipient capital flows, that in turn

\footnotetext{
${ }^{13}$ Ideally, we would want to scale by total assets and liabilities of the economy, including domestic assets, but do not have data allowing this.

${ }^{14}$ Calculations of private capital flows measures are explained in the note of Figure 5 below as well as in Appendix Table A2.
} 
stunts further capital flows. In contrast, when authorities in countries with managed exchange rate regimes use interventions to prevent such exchange rate adjustments, we tend to see greater realized private capital flows in response to changes in global financial factors. This point is relevant in our country sample, which represents different exchange rate regimes. We hence check the robustness of our results to using an exchange market pressure index (EMP), constructed in Goldberg and Krogstrup (2018), as a measure of net capital flow pressures that is comparable across countries with different exchange rate regimes. We also check robustness of our results to including a measure of the exchange rate regime in the baseline regressions. Our main findings are robust to these alternative specifications.

\section{B. Global Factors in Capital Flows and Domestic Financial Institutional Structure}

We take two complementary approaches to investigating the association between capital flows and foreign risk exposures of resident financial institutions. First, the literature finds that global risk factors affect capital flows differently during crisis times than during normal times (Avdjiev et al 2017, Goldberg and Krogstrup 2018). We therefore have a first look at cross country patterns of capital flows during the height of the GFC. The GFC is associated with particularly elevated global risk factors as reflected in largely all available metrics of global risk, and notably the VIX. The second approach is to take advantage of the time series dimension and consider average responses to global risk conditions in panel setting. We carry out a panel regression analysis that relates the global risk sensitivity of capital flows to financial institutions' foreign exposure, while controlling for other factors.

To measure how capital flows differed from normal levels during the GFC, we consider average quarterly private capital flows in percent of total private foreign positions during the two quarters of 2008Q4 and 2009Q1, relative to the flows prevailing two years earlier (2006Q4 and 2007Q1), when market responses to the brewing crisis had not yet erupted. ${ }^{15}$ Figure 5 presents three scatter plots of the change in net capital flows during the GFC against the foreign exposure of total financial institution, banks and nonbanks respectively. The Figure is suggestive of a weakly positive relationship between crisis related capital inflows and domestic financial institutions' foreign exposure. This is consistent with the hypothesis that financial institutions with net long exposures repatriate foreign investments or increase foreign funding to reduce the long exposure when risks increase. The relationship is also discernible in banks' and nonbanks' foreign exposures individually. A similar pattern emerges if we plot changes in gross capital inflows or exchange market pressures against the net foreign exposure of financial institutions. Many other factors could drive this positive relationship, however. To take advantage of the time series variation in addition to cross country variation, and to control for other factors, we hence carry out a regression analysis next.

\footnotetext{
${ }^{15}$ Since the first signs of the GFC emerged in the summer of 2007, we find it more prudent to compare with flows two years before, instead of using a more conventional year-on-year measure. In the case of Bolivia, we have considered flows during the crisis relative to flows prevailing three years earlier, as capital flows in Bolivia in 2006 were strongly affected by large nationalizations of foreign held possessions related to oil and gas.
} 


\section{Panel Regression Analysis}

Following IMF (2014), Cerutti et al. (2015) and Krogstrup and Tille (2018), we run a fixed effects panel regression for capital flows as a share of total foreign positions on the VIX and an interaction term with the VIX and the net foreign exposure of financial institutions:

$\operatorname{Cflows}_{i, t}=a_{i}+b 1 * \operatorname{dlog}\left(V I X_{t-1}\right)+b 2 * \operatorname{dlog}\left(V I X_{t-1}\right) * \operatorname{NETEX} P_{i, t-1}^{j}+b 3 * N E T E X P_{i, t-1}^{j}+$ $b 4 *$ control $_{i, t-1}+\varepsilon_{i, t}$,

where $i$ is a country subscript, $t$ is time (quarter), $j$ refers to the types of institutions considered (all financial institutions, banks or nonbanks), and control represents a set of control variables.

We use five different capital flow measures as dependent variable: net capital inflows, net bank inflows, gross capital inflows by non-residents, gross capital inflows by residents (defined as resident gross capital outflows multiplied by minus one for comparability with gross non-resident inflows), and the EMP. ${ }^{16}$ The three panels of Tables 2 contain the regression results when interacting the VIX with net exposure of total financial institutions, banks and nonbanks respectively. Table 3 zooms in on the results using nonbank foreign exposure and contains robustness to interacting the VIX with financial depth, net foreign assets, exchange rate regime (dummy for countries with a peg) and capital controls (the Chinn Ito index), as well as to excluding oil countries, AEs and excluding the financial crisis. ${ }^{17}$

\footnotetext{
${ }^{16}$ A detailed description of the different capital flows measures is available in Appendix Table A2.

${ }^{17}$ Similar regression results using total financial institutions' net foreign exposure as well as banks' net foreign exposure are reported in Annex E, Tables A3 and A4. Estimation results for different sample periods are reported in Tables A5 and A6. All robustness checks point to the role of nonbank exposure to significant increases in net capital inflows when global risks heightened, whereas the relation is not seen in bank exposure.
} 
Figure 5. Change in Net Capital Inflows in the Global Financial Crisis

a. Total financial institutions' net foreign exposure

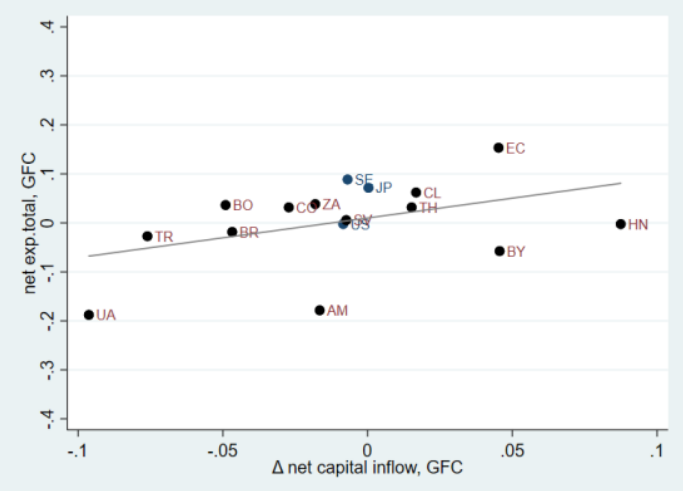

b. Banks' net foreign exposure

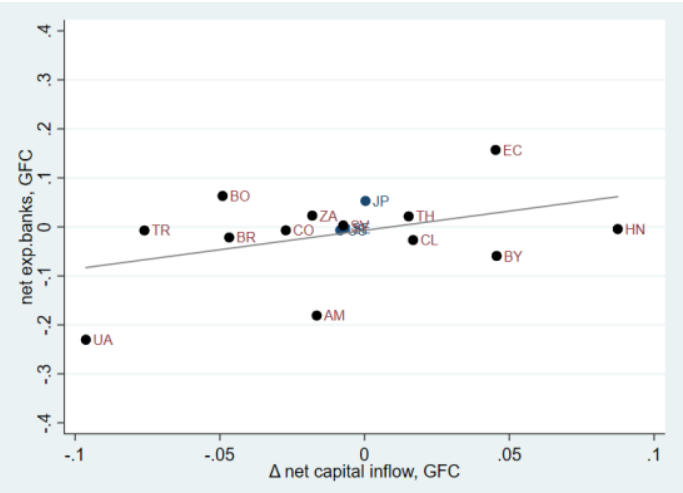

c. Nonbank financial institutions' net foreign exposure

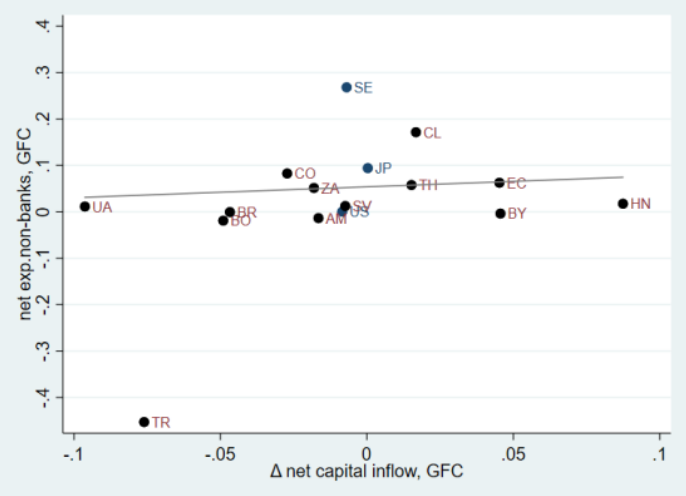

Note: Net capital inflows are defined as the average quarterly private capital flows in percent of total private foreign positions in 2008Q4 and 2009Q1, relative to the flow prevailing in the same quarters two years earlier (2006Q4 and 2007Q1). For Bolivia, we compare with three years earlier due to data anomalies in 2006 related to large nationalizations. Net exposure variables on the vertical axis are those used in Figure 4. Changes in net capital inflow variables on the horizontal axis are the same one used in Figure 5. The lines in charts show the fitted values, excluding outliers: Turkey for chart $\mathrm{c}$. 


\section{Results and Robustness}

The coefficients for the VIX alone are significant for gross flows but not for net flows. This finding is consistent with Adler et al. (2016) in that capital flow responses to global risk factors often reflect repatriation and offsetting retrenchment flows.

We find that the net exposure to foreign assets increases the response of net capital flows to the VIX and turns the coefficient significant. The parameter estimate for the VIX interacted with net exposure indicates that net capital inflows increase in response to higher global risk factors when resident financial institutions are long in foreign exposure. Conversely, inflows decline in response to higher global risk factors when resident financial institutions are net short in foreign exposure. The same pattern is found in the gross non-resident inflow regression, suggesting that the net long exposure is reduced by increasing foreign liabilities (i.e. a gross non-resident capital inflow). The relationship is not significant in the gross resident inflow regression, however, suggesting that on-balance sheet foreign asset repatriations or increases in foreign asset purchases are not the main drivers of the net capital flow response to global risk factors. The finding is unlikely to reflect a generalized foreign investor retrenchment, i.e. a negative push factor, as this should show up in the parameter estimate for the VIX alone rather than in the interaction term. Adjustments of foreign liabilities by resident financial institutions in response to global risk factors are not uncommon (see also Krogstrup and Tille 2018). We discuss portfolio management practices using derivatives that are consistent with foreign liabilities adjustments in Section IV below.

The regression results of Table 2 also suggest that nonbank foreign exposure matters more than bank foreign exposure. When the VIX increases, a larger foreign exposure of nonbanks significantly increases the total net capital inflow response as well as the response of net bank-related inflows. Again, the interaction term is significant for gross non-resident inflows, but not for gross resident inflows. Moreover, it is insignificant in the net bank inflow regression when bank foreign exposure is considered.

We find that there are differences across the AE and EM samples. The association between nonbank exposures and the sensitivity of bank-specific flows to the VIX is driven by advanced economies, and US in particular, while not significant in regressions based on the EM sample alone, as shown in appendix Tables A7 and A8. Nonbank foreign exposures continue to matter more for the sensitivity of capital flows than bank foreign exposures when advanced economies are excluded, however.

We run a series of robustness tests. First, the results are robust to the sample period used, including when the global financial crisis period is left out, as shown in Appendix Tables A3 and A4. 
Table 2. Panel Regression Results

(a) Net exposure for total financial institutions

\begin{tabular}{|c|c|c|c|c|c|}
\hline & $\begin{array}{c}\text { net capital } \\
\text { inflows }\end{array}$ & $\begin{array}{c}\text { netbank } \\
\text { inflows }\end{array}$ & $\begin{array}{l}\text { gross non- } \\
\text { resident inflows }\end{array}$ & $\begin{array}{c}\text { gross resident } \\
\text { inflows }\end{array}$ & EMP \\
\hline \multirow[t]{2}{*}{$\operatorname{dlog}(\mathrm{VIX})$} & -0.004 & 0.001 & $-0.009^{* * *}$ & $0.010^{* *}$ & $-0.041^{* \cdots *}$ \\
\hline & $(0.003)$ & $(0.002)$ & $(0.003)$ & $(0.004)$ & $(0.014)$ \\
\hline \multirow[t]{2}{*}{$\operatorname{dlog}(V \mid X) \_N E T E X P_{F G,-1}$} & $0.068^{\circ}$ & -0.013 & $0.042^{* *}$ & 0.009 & $0.290^{* *}$ \\
\hline & $(0.035)$ & $(0.034)$ & $(0.019)$ & $(0.046)$ & $(0.122)$ \\
\hline \multirow[t]{2}{*}{ NETEXP $P_{F, ; 1}$} & 0.068 & 0.031 & 0.010 & $0.060^{* *}$ & $0.178^{* *}$ \\
\hline & $(0.047)$ & $(0.025)$ & $(0.045)$ & $(0.024)$ & $(0.078)$ \\
\hline \multirow[t]{2}{*}{$d\left(i^{*}\right)$} & 0.005 & -0.000 & $0.005^{* *}$ & -0.002 & $-0.023^{* *}$ \\
\hline & $(0.004)$ & $(0.001)$ & $(0.003)$ & $(0.001)$ & $(0.009)$ \\
\hline \multirow[t]{2}{*}{$d\left(i^{*}{ }_{s x}\right)$} & -0.006 & -0.001 & -0.006 & 0.001 & -0.019 \\
\hline & $(0.004)$ & $(0.002)$ & $(0.004)$ & $(0.004)$ & $(0.021)$ \\
\hline R_squared & 0.02 & 0.01 & 0.02 & 0.02 & 0.04 \\
\hline Adj. R_squared & 0.01 & $0 . \infty 0$ & 0.01 & 0.01 & 0.03 \\
\hline Nobs & 988 & 984 & 988 & 988 & 993 \\
\hline No.cross sections & 24 & 24 & 24 & 24 & 23 \\
\hline Fixed effects & Yes & Yes & Yes & Yes & Yes \\
\hline
\end{tabular}

(b) Net exposure for banks

\begin{tabular}{|c|c|c|c|c|c|}
\hline & $\begin{array}{l}\text { net capital } \\
\text { inflows }\end{array}$ & $\begin{array}{l}\text { net bank } \\
\text { inflows }\end{array}$ & $\begin{array}{l}\text { gross non- } \\
\text { resident inflows }\end{array}$ & $\begin{array}{c}\text { gross resident } \\
\text { inflows }\end{array}$ & EMP \\
\hline$d \log [V(X]$ & $\begin{array}{l}-0.002 \\
{[0.003]}\end{array}$ & $\begin{array}{c}0.001 \\
(0.002)\end{array}$ & $\begin{array}{c}-0.008^{* * *} \\
{[0.003]}\end{array}$ & $\begin{array}{l}0.010^{* *} \\
{[0.004)}\end{array}$ & $\begin{array}{c}-0.034^{* *} \\
{[0.013)}\end{array}$ \\
\hline$d \log [V X] \_N E T E X P_{B, h 1}$ & $\begin{array}{c}0.063 \\
{[0.041)}\end{array}$ & $\begin{array}{l}-0.019 \\
{[0.035)}\end{array}$ & $\begin{array}{l}0.042^{*} \\
{[0.023]}\end{array}$ & $\begin{array}{c}0.010 \\
{[0.049)}\end{array}$ & $\begin{array}{l}0.321^{* *} \\
{[0.155]}\end{array}$ \\
\hline NETEXXP $\$$ & $\begin{array}{c}0.072 \\
{[0.045]}\end{array}$ & $\begin{array}{r}0.039 \\
(0.024)\end{array}$ & $\begin{array}{c}0.007 \\
{[0.042)}\end{array}$ & $\begin{array}{c}0.064^{* * * *} \\
(0.021)\end{array}$ & $\begin{array}{l}0.173^{* *} \\
{[0.068)}\end{array}$ \\
\hline$d\left[i^{*}\right)$ & $\begin{array}{c}0.005 \\
(0.004)\end{array}$ & $\begin{array}{l}-0.000 \\
(0.002)\end{array}$ & $\begin{array}{l}0.005^{*} \\
(0.003)\end{array}$ & $\begin{array}{l}-0.002 \\
(0.001)\end{array}$ & $\begin{array}{c}-0.024^{* *} \\
{[0.009]}\end{array}$ \\
\hline$d\left[i^{*} \mathrm{se}\right]$ & $\begin{array}{l}-0.006 \\
{[0.004)} \\
\end{array}$ & $\begin{array}{l}-0.001 \\
(0.002) \\
\end{array}$ & $\begin{array}{l}-0.006 \\
{[0.004]} \\
\end{array}$ & $\begin{array}{c}0.001 \\
(0.004) \\
\end{array}$ & $\begin{array}{l}-0.019 \\
{[0.021)} \\
\end{array}$ \\
\hline R_squared & 0.02 & 0.02 & 0.02 & 0.02 & 0.04 \\
\hline Adj. R_squared & 0.01 & 0.01 & 0.01 & 0.02 & 0.03 \\
\hline Nobs & 988 & 984 & $98 B$ & $98 B$ & 993 \\
\hline No.cross sections & 24 & 24 & 24 & 24 & 23 \\
\hline Fixed effects & Yes & Yes & Yes & Yes & Yes \\
\hline
\end{tabular}

(c) Net exposure for nonbanks

\begin{tabular}{|c|c|c|c|c|c|}
\hline & $\begin{array}{l}\text { netcapital } \\
\text { inflows }\end{array}$ & $\begin{array}{l}\text { net bank } \\
\text { inflows }\end{array}$ & $\begin{array}{l}\text { gross non- } \\
\text { resident inflows }\end{array}$ & $\begin{array}{l}\text { gross resident } \\
\text { inflows }\end{array}$ & EMP \\
\hline \multirow[t]{2}{*}{$\operatorname{dlog}(V I X)$} & -0.003 & 0.001 & $-0.009^{* * *}$ & $0.011^{* *}$ & $-0.040^{* * *}$ \\
\hline & $(0.003)$ & $(0.002)$ & $(0.003)$ & $(0.004)$ & $(0.014)$ \\
\hline \multirow[t]{2}{*}{ 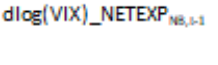 } & $0.050^{* *}$ & $0.021^{* *}$ & $0.023^{*}$ & 0.018 & $0.175^{* * *}$ \\
\hline & $(0.021)$ & $(0.009)$ & $(0.012)$ & $(0.018)$ & $(0.061)$ \\
\hline \multirow[t]{2}{*}{ NETEXP } & -0.002 & -0.002 & 0.015 & -0.028 & 0.014 \\
\hline & $(0.037)$ & $(0.013)$ & $(0.026)$ & $(0.032)$ & $(0.094)$ \\
\hline \multirow[t]{2}{*}{$d\left(i^{*}\right)$} & 0.005 & -0.000 & $0.005^{* *}$ & -0.002 & $-0.024^{* * *}$ \\
\hline & $(0.004)$ & $(0.002)$ & $(0.002)$ & $(0 . \infty 01)$ & $(0.008)$ \\
\hline \multirow[t]{2}{*}{$d\left(i^{*}{ }_{s}\right)$} & -0.006 & -0.001 & -0.006 & 0.001 & -0.020 \\
\hline & $(0.005)$ & $(0.002)$ & $(0.004)$ & $(0.004)$ & $(0.020)$ \\
\hline R_squared & 0.01 & 0.00 & 0.02 & 0.01 & 0.03 \\
\hline Adj. R_squared & 0.01 & -0.00 & 0.01 & 0.01 & 0.03 \\
\hline Nobs & 988 & 984 & 988 & 988 & 993 \\
\hline No.cross sections & 24 & 24 & 24 & 24 & 23 \\
\hline Fixed effects & Yes & Yes & Yes & Yes & Yes \\
\hline
\end{tabular}

Note: Results are based on quarterly panel regressions, sample period from 2002Q1 to 2017Q4. Gross non-resident inflows are gross inflows into foreign liabilities. Gross resident inflows are defined as gross resident purchases of foreign assets multiplied by minus one. Nobs gives the number of regression observations. No.cross sections indicates the number of countries included. Fixed effects indicate country fixed effects. Numbers in parentheses are standard errors. Asterisks ${ }^{*},{ }^{* *}$ and ${ }^{* * *}$ indicate significance at the 10, 5 percent and 1 percent levels, respectively, using robust clustered standard errors and covariances. The first three capital flows measures are those used in Figure 5. 
Table 3 presents the regression results for net capital flows when including various control variables. Column I reproduces the baseline results in column (c) of Table 2 for comparison. Column II shows that the significance of the interaction term remains when oil-exporting countries are excluded. Significance also remains when controlling for financial depth (column III), for the net total foreign asset position in percent of total assets and liabilities of a country (column IV), for pegging the exchange rate (column V), and for capital controls (column VI). It is also robust to excluding AEs from the sample (column VII), where the parameter estimate becomes slightly larger and more significant. Moreover, the interaction term is not driven only by the GFC episode (column VIII). Finally, column IX includes time fixed effects to control for any global push factors beyond what is captured by the VIX. Time effect for example capture foreign investor supply effects of adjusting supply of gross foreign liabilities. The interaction term with the VIX survives, making it less likely that net inflows reflect foreign supply factors. The significant interaction term in the gross non-resident inflow regression is also robust to including time fixed effects (not shown). 
Table 3. Robustness: Net Capital Flows Specification with Nonbank Exposure.

\begin{tabular}{|c|c|c|c|c|c|c|c|c|c|}
\hline & 1 & II & III & IV & $\mathrm{V}$ & VI & VII & VIII & IX \\
\hline \multirow[t]{2}{*}{ dlog(VIX) } & -0.003 & -0.002 & 0.001 & -0.004 & $-0.008^{* *}$ & -0.003 & -0.002 & -0.005 & \\
\hline & $(0.003)$ & $(0.003)$ & $(0.005)$ & $(0.003)$ & $(0.003)$ & $(0.002)$ & $(0.003)$ & $(0.003)$ & \\
\hline \multirow[t]{2}{*}{ dlog(VIX)_NETEXP $P_{\mathrm{NB}, \mathrm{t} 1}$} & $0.050^{\circ *}$ & $0.047^{* *}$ & $0.063^{* *}$ & $0.053^{* *}$ & $0.044^{* *}$ & $0.047^{* *}$ & $0.078 \cdots$ & $0.048^{* *}$ & $0.046^{* *}$ \\
\hline & $(0.021)$ & $(0.022)$ & $(0.023)$ & $(0.024)$ & $(0.018)$ & $(0.021)$ & $(0.019)$ & $(0.021)$ & $(0.022)$ \\
\hline \multirow[t]{2}{*}{ NETEXP $_{\mathrm{NB}, \mathrm{t} 1 \mathrm{I}}$} & -0.002 & 0.005 & -0.001 & -0.005 & 0.028 & -0.002 & -0.000 & -0.017 & 0.021 \\
\hline & $(0.037)$ & $(0.038)$ & $(0.038)$ & $(0.040)$ & $(0.028)$ & $(0.036)$ & $(0.039)$ & $(0.037)$ & $(0.043)$ \\
\hline \multirow[t]{2}{*}{$d\left(i^{*}\right)$} & 0.005 & 0.005 & 0.005 & 0.005 & 0.005 & 0.005 & 0.005 & 0.004 & 0.004 \\
\hline & $(0.004)$ & $(0.004)$ & $(0.004)$ & $(0.004)$ & $(0.004)$ & $(0.004)$ & $(0.004)$ & $(0.004)$ & $(0.004)$ \\
\hline \multirow[t]{2}{*}{$d\left(i^{*}{ }_{S R}\right)$} & -0.006 & -0.006 & -0.005 & -0.006 & -0.006 & -0.006 & -0.007 & -0.005 & 0.002 \\
\hline & $(0.005)$ & $(0.005)$ & $(0.004)$ & $(0.004)$ & $(0.005)$ & $(0.005)$ & $(0.006)$ & $(0.004)$ & $(0.005)$ \\
\hline \multirow[t]{2}{*}{ findepth $_{t 1}$} & & & -0.002 & & & & & & \\
\hline & & & $(0.006)$ & & & & & & \\
\hline \multirow[t]{2}{*}{ dlog(VIX)_findepth $t_{1}$} & & & -0.003 & & & & & & \\
\hline & & & $(0.002)$ & & & & & & \\
\hline \multirow[t]{2}{*}{ dlog(VIX)_NFA } & & & & -0.002 & & & & & \\
\hline & & & & $(0.006)$ & & & & & \\
\hline \multirow[t]{2}{*}{$\mathrm{NFA}_{\mathrm{t}}$} & & & & 0.006 & & & & & \\
\hline & & & & $(0.012)$ & & & & & \\
\hline \multirow[t]{2}{*}{ dlog(VIX)_peg } & & & & & $0.013^{* *}$ & & & & \\
\hline & & & & & $(0.006)$ & & & & \\
\hline \multirow[t]{2}{*}{ peg } & & & & & -0.006 & & & & \\
\hline & & & & & $(0.007)$ & & & & \\
\hline \multirow[t]{2}{*}{ dlog(VIX)_kaopen } & & & & & & 0.001 & & & \\
\hline & & & & & & $(0.002)$ & & & \\
\hline \multirow[t]{2}{*}{ kaopen } & & & & & & -0.002 & & & \\
\hline & & & & & & $(0.005)$ & & & \\
\hline R_squared & 0.01 & 0.01 & 0.01 & 0.01 & 0.02 & 0.01 & 0.02 & 0.01 & 0.11 \\
\hline Adj. R_squared & 0.01 & 0.01 & 0.01 & 0.01 & 0.01 & 0.01 & 0.01 & 0.00 & 0.04 \\
\hline Nobs & 988 & 919 & 988 & 987 & 968 & 988 & 806 & 960 & 988 \\
\hline No.cross sections & 24 & 21 & 24 & 24 & 23 & 24 & 21 & 24 & 24 \\
\hline Fixed effects & Yes & Yes & Yes & Yes & Yes & Yes & Yes & Yes & Yes \\
\hline Time effects & No & No & No & No & No & No & No & No & Yes \\
\hline
\end{tabular}

Note: The sample period runs from 2002Q1 to 2017Q4. Column I is identical to Table 2 (c), the first column regression. Column II excludes oil countries Armenia, Georgia and Kazakhstan. Column VII excludes Advanced Economies from the sample. Column VIII excludes the observations specific to the Global Financial Crisis. Numbers in parentheses are standard errors. Asterisks ${ }^{*},{ }^{* *}$ and ${ }^{* * *}$ indicate significance at the 10, 5 percent and 1 percent levels, respectively, using robust clustered standard errors and covariances.

\section{An Interpretation: Nonbank Risk Management Practices and Flows}

The relationships between nonbanks' foreign exposure and bank net capital inflows in advanced economies, and in the US, and the reflection mainly in gross capital inflows, offer new perspectives on findings in the earlier empirical literature. Milesi-Ferretti and Tille (2011) show that the built-up and subsequent collapse of cross-border gross financial positions during the global financial crisis were mainly driven by international bank credit and deposits. These findings have been taken to suggest that banks were adjusting their portfolios in response to global shocks to a greater degree than other institutions. 
An alternative interpretation considering our findings is that these bank flows reflect, to some extent, risk-management operations of bank clients rather than bank portfolio adjustments per se. Non-bank financial institutions respond to and manage risks in diverse ways, but generally exhibit elements of risk aversion and often rely on value-at-risk methods that are endogenous to global risk conditions (e.g. Adrian and Shin 2010). Krogstrup and Tille (2018) show that risk aversion implies that perceived increases in risk associated with a given exposure triggers portfolio adjustment that reduce the exposure. An increase in global risk perceptions, for example related to the foreign currency risk of foreign asset positions, can be addressed temporarily by selling foreign currency forward in exchange for domestic currency, or by engaging in foreign currency swap funding, in addition to outright selling of foreign currency assets. Banks act as market makers in such foreign currency hedging instruments. They earn fees and spreads but do not necessarily want the associated exposure, which they in turn hedge in the international interbank money market. These risk-offsetting money market transactions are on-balance sheet and hence reflected in the balance of payments, whereas the derivatives operations with non-bank clients they are meant to off-set are not. How exactly the off-setting money market operations are recorded in the balance of payments depends on the nature of the derivatives instruments and counterparties of the transactions.

A typical but highly stylized example, consistent with our empirical results, is illustrated in Figure 6, following Hansen and Krogstrup (2019). The left captures foreign institutions while the right reflects home financial institutions. Arrows reflect transactions, and arrows crossing the dotted vertical line down the middle reflect transactions recorded as capital flows in the balance of payments. The lower right-side box is a nonbank investor with a net long exposure to foreign currency denominated assets. If risks associated with foreign currency increase (e.g. global market conditions tighten), this investor will seek to reduce her long foreign currency exposure. This can be done by selling foreign currency assets outright, as reflected by the lower blue allow from the foreign securities markets. A sale of a foreign asset would be recorded as a gross resident capital inflow (negative gross resident outflow, a retrenchment). Alternatively, the investor can reduce her long exposure by selling foreign currency forward to her bank connection, receiving instead domestic currency at a specified future date, as reflected in the dotted red arrows from the non-bank to the resident bank. These off-balance sheet transactions are not recorded in balance sheet data, nor in the balance of payments. The resident bank in turn covers its resulting increase in long foreign currency exposure by borrowing a corresponding amount of foreign currency in the interbank spot market, with a maturity matching the forward contract. This transaction is reflected in the solid red arrow from the foreign bank to the resident bank and recorded as a gross nonresident bank inflow in the balance of payments. When the forward contract matures, the resident bank receives foreign currency from its non-bank client, which it then uses to pay down its foreign currency funding. Alternatively, the bank could reduce its holdings of foreign currency assets, as reflected in the dotted blue line. This would be recorded as a bank asset retrenchment. 
Figure 6. Portfolio Adjustments to Foreign Risks and Capital Flows: A Stylized Example

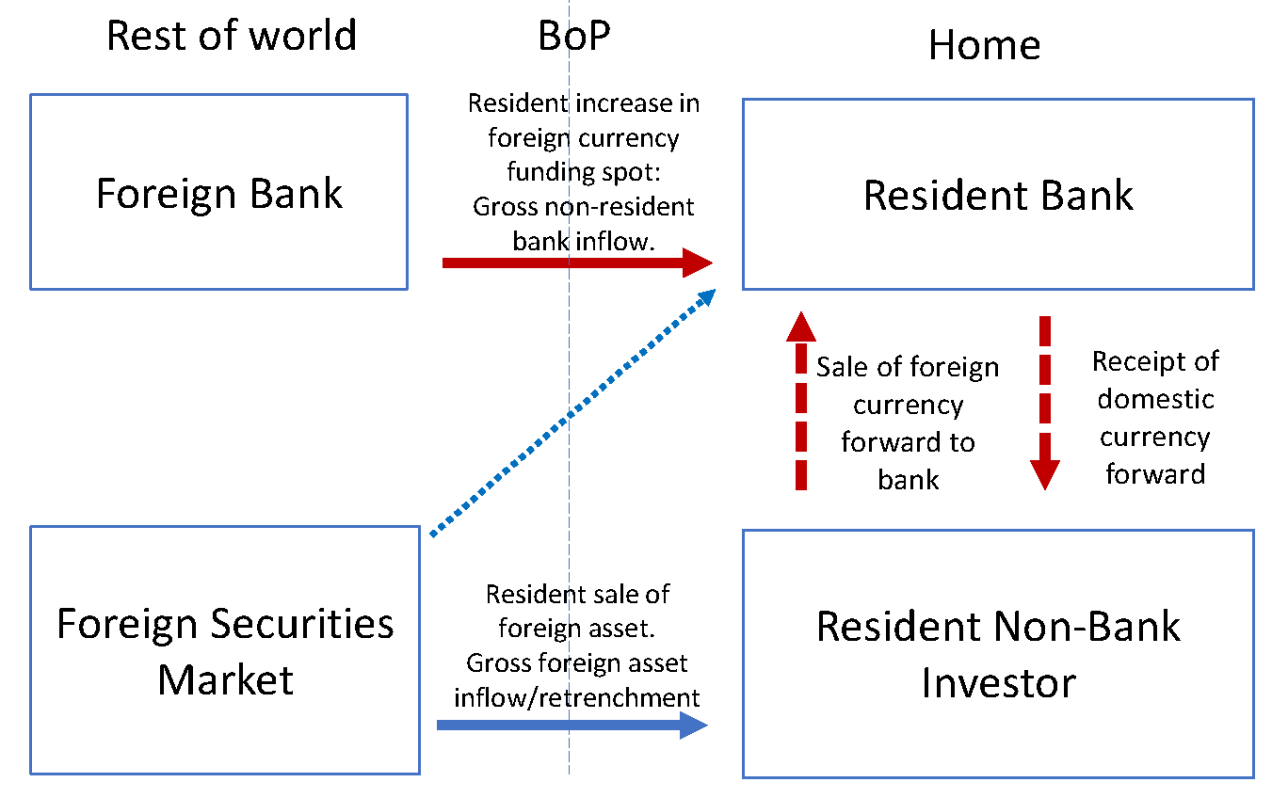

Note: Authors' own illustrations of transactions that can reduce a long foreign exposure of a resident non-bank. Based on Hansen and Krogstrup (2019). The details are explained in the text.

The Figure depicts the specific example where the resident non-bank engages with a domestic bank in FX derivatives transactions. If instead the counterparty were a foreign bank, another non-bank, or if the foreign currency swap market were used, the arrows crossing the balance of payments would look similar but could be coming from different domestic or foreign counterparties. The point is that capital flows recorded between specific types of counterparties will not always reflect who is ultimately driving these flows. The predominance of bank liability flows in responding to global risk conditions may in fact mask portfolio adjustment by banks' nonbank clients.

Variants of these mechanisms notably drove cross border capital flows during a large capital flow episode in Denmark in early 2015, and in Korea more generally, as described in the Box below.

\section{Box: Foreign Currency Hedging by Nonbanks and Bank Capital Flows: Case Studies}

Investors typically use the forward market to hedge exchange rate risks of their positions by selling or purchasing currencies in forward contracts. Usually they enter into forward contracts with their correspondent banks. Banks in turn hedge the exchange rate risks implied by the forward contract by adjusting their foreign assets holdings, leading to bank capital flows which ultimately reflect nonbank rather than bank portfolio balancing behavior. Below are two country case studies of these types of capital flows. 
Denmark: The long-standing peg of the Danish krone against the euro came under unusually large pressure as volatility in international financial market rose following the Swiss National Bank's decision to remove the cap on the Swiss franc against the euro on January 15, 2015. Concerns about the viability of the otherwise highly credible Danish krone peg prompted domestic institutional investors to increase the hedging of the foreign currency risk related to their holdings of foreign assets. Danish institutional investors, and pension funds in particular, hold substantial amounts of foreign assets, the currency exposure of which is typically not fully hedged. The increase in the risk associated with the appreciation pressures on the krone in 2015 increased the perceived value at risk of these large foreign asset holdings, triggering an increased demand for hedging of currency risk. Rather than selling foreign assets, the pension funds increased their hedging through purchases of kroner forward against euro from Danish banks. The banks, taking the other side of these forwards, sold euros spot against kroner to hedge the exchange risk of the positions. These transactions were recorded as bank related capital inflows (bank retrenchment), while the flows ultimately reflected the hedging demand of institutional investors as currency risk and volatility increased. The resulting appreciation pressures on the Danish krone were contained by massive interventions and interest rate cuts into negative territory by Danmarks Nationalbank (Danmarks Nationalbank 2015).

Korea: In Korea, banks' use of foreign currency funding has been directly linked with their nonbank costumers' demand for currency hedging. Demand for currency hedging has typically tended to derive from Korean exporters, importers and asset management companies (AMCs). More recently, insurance funds and the national pension fund have increased their holdings of foreign currency assets. Institutional investors tend to be funded in domestic currency and use currency forward contracts to hedge some of the associated currency mismatch of investing abroad. Exporters purchase domestic currency forward against US dollars while importers purchase US dollars forward against Korean won to hedge the currency exposure of future cash flows. However, importer' demand for US dollars forward has tended to fall short of exporters' and institutional investors' demand for Korean won forward. Banks in Korea are market makers in the forward market and close this gap. They in turn hedge the associated currency exposure through taking up US dollar spot funding in interbank money markets. ${ }^{18}$ Banks' external borrowing and crossborder bank flows are thus linked to and reflect domestic nonbank currency risk management activities rather than bank portfolio choices. Changes in these positions are driven by changes in the currency hedging demand of nonbanks, which may fluctuate with investor risk aversion and currency market volatility. During the global financial crisis, Korean banks' maturity of funding positions did not match the maturity of the forward contracts, resulting in US dollar squeezes. (Sangdai, et al. BIS Papers No 73; Ree et al. 2012, Hansen and Krogstrup 2019)

\footnotetext{
${ }^{18}$ Domestic banks typically borrow USD from foreign bank branches, and foreign bank branches in turn borrow USD from their foreign headquarters.
} 
Indicators of bank-nonbank interconnectedness suggest it is high in many countries, further underlining the possibility that portfolio risk management behaviors of nonbanks play a role in cross-border bank flows and gross liabilities flows, notably during turbulent market episodes. According to the FSB's Global Shadow Banking Monitoring Report 2017 (FSB 2018), banks' exposure to nonbanks (as a sum of assets and liabilities) for Brazil and South Africa is around 20 percent of total bank assets, and is also high in the cases of Indonesia, Turkey, and South Africa. ${ }^{19}$ The FSB report moreover points to high interconnectedness of nonbanks with the rest of the world for some countries (for example, Indonesia, US, and Brazil among our sample countries). ${ }^{20}$

\section{Conclusion}

The sensitivity of capital flows to global financial conditions, and drivers of bank flows, are not yet well understood, but central for devising appropriate policy responses to disruptive capital flow volatility. The previous literature has focused on the role of global financial factors and addressed the role of banks in responding to these. Based on a new and previously unexplored dataset, the SRF data, we have presented new empirical evidence on the role nonbank financial institutions' foreign exposures in driving cross border capital flow responses to global risk conditions. Panel regression analysis has shown that cross-border capital flow responses to global financial conditions, as measured by the VIX, is associated with foreign exposures in the balance sheets of nonbanks. The flows are reflected mainly in gross non-resident inflows, and in bank flows in advanced economies.

We have offered a specific interpretation of these findings. Banks tend to be relatively well hedged against foreign risks, while this is less the case for nonbanks such as real institutional investors. To the extent that nonbanks hedge risks dynamically, they may respond to changes in global risk conditions by increasing their hedging of risks. They can do this directly by buying and selling foreign assets, or by entering into derivatives contracts. When nonbanks offload risk to resident banks using derivatives contracts, the banks in turn may offload this risk in the interbank markets, giving rise to bank capital flows that are ultimately driven by nonbank risk management behavior. If the counterparties are nonbanks or foreign banks, the flows can look different.

The findings suggest that changes in the mix of financial institutional structure over time can contribute to shifting capital flow volatility and sensitivity to global risk conditions.

Moreover, the way in which nonbank financial institutions are regulated in terms of their risk management may directly affect capital flow volatility through the suggested mechanisms.

\footnotetext{
${ }^{19}$ See Exhibit 3-4, 3-7 and 3-9, pages 37, 39 and 41of the FSB 2018. Country coverage is different between the FSB's report and our paper, and "nonbanks" are further categorized into OFIs, pension funds and insurance funds in the FSB report.

${ }^{20}$ Exhibit 3-12, page 44 of the FSB 2018.
} 
This points to some important policy implications. Macroprudential and capital flow management measures could, in some cases, beneficially be extended to include regulation of foreign exposures and risk management practices of nonbank financial institutions.

Finally, the analysis underlines the usefulness and need for more detailed and complete data on the structure of financial systems and financial balance sheets for analyzing the drivers of cross border capital flows. Our dataset is unique in allowing a perspective on nonbank balance sheets, but the sample is small, and off-balance sheet positions are not recorded. Given that capital flows have become larger and more volatile, and that the financial institutional structure and the role of financial intermediaries have shifted, a better understanding of the behavior of nonbanks and effects on financial volatility has become more important.

\section{REFERENCES}

Abad, Jorge, Marco D'Errico, Neill Killeen, Vera Luz, Tuomas Peltonen, Richard Portes, and Teresa Urbano, 2017. "Mapping the interconnectedness between EU banks and shadow banking entities," European Systemic Risk Board Working Paper No 40.

Adler, Gustavo, Marie-Louise Djigbenou, and Sebastian Sosa, 2016. "Global financial shocks and foreign asset repatriation: Do local investors play a stabilizing role?," Journal of International Money and Finance, 2016, Vol 60, issue C, 8-28.

Adrian, Tobias and Hyun Song Shin, 2010. "Liquidity and leverage," Journal of Financial Intermediation, 2010, vol. 19, issue 3, 418-437.

Adrian, Tobias and Nina Boyarchenko, 2013. "Intermediary balance sheets," Staff Report 651, Federal Reserve Bank of New York.

Aizenman, Joshua, Menzie D. Chinn and Hiro Ito, 2015. "Monetary Policy Spillovers and the Trilemma in the New Normal: Periphery Country Sensitivity to Core Country Conditions," NBER Working Paper No. 21128.

Alfaro, Laura, Sebnem Kalemli-Ozcan, and Vadym Volosovych, 2014. "Sovereigns, Upstream Capital Flows, and Global Imbalances," Journal of the European Economic Association, European Economic Association, vol. 12(5), pages 1240-1284, October.

Avdjiev, Stefan, Leonardo Gambacorta, Linda S. Goldberg, and Stefano Schiaffi, 2017. "The shifting drivers of global liquidity," CEPR Working Paper, 12127.

Bank for International Settlement, 2016. BIS Quarterly Review, December 2016, December 2016. 
Bernanke, Ben and Mark Gertler, 1989. “Agency Costs, Net Worth, and Business Fluctuations," American Economic Association.

Borio, Claudio, Robert N McCauley and Patrick McGuire, 2017. "FX swaps and forwards: missing global debt?” BIS Quarterly Review.

Brookings, 2012. "Banks and Cross-Border Capital Flows: Policy Challenges and Regulatory Responses, Committee on International Economic Policy and Reform."

Bruno, Valentina and Hyun Song Shin (2015a), "Capital flows and the risk-taking channel of monetary policy", Journal of Monetary Economics 71: 119-132.

Bruno, Valentina and Hyum Song Shin (2015b), "Cross-border banking and global liquidity", Review of Economic Studies 82: 535-564.

Bruno, Valentina and Hyun Song Shin, 2017. "Currency Depreciation and Emerging Market Corporate Distress," Available at SSRN: https://ssrn.com/abstract=2883488 or http://dx.doi.org/10.2139/ssrn.2883488.

Cerutti, Eugenio M., Stijn Claessens and Lev Ratnovski (2014), "Global liquidity and drivers of cross-border bank flows", IMF working paper 14/69.

Cerutti, Eugenio M., Stijn Claessens and Damien Puy, 2015. "Push Factors and Capital Flows to Emerging Markets: Why Knowing Your Lender Matters More Than Fundamentals," IMF Working Paper No. 15/127

Cetorelli, Nicola and Linda S. Goldberg, 2012 "Banking Globalization and Monetary Transmission" Journal of Finance, Vol. 67 (5), October.

Cetorelli, Nicola and Linda S. Goldberg, 2011 "Global Banks and International Shock Transmission: Evidence from the Crisis," IMF Economic Review 59, September.

Danmarks Nationalbank, 2015. "The Danish krone under pressure in January-February 2015," Monetary Review 1st Quarter.

Devereux, Michael B. and James Yetman, 2010. "Leverage Constraints and the International Transmission of Shocks," Journal of Money, Credit and Banking, Blackwell Publishing, vol. 42(s1), pages 71-105, September.

Financial Stability Board, 2018. "Global Shadow Banking Monitoring Report 2017," March 2018.

Forbes, Kristin J. and Francis E. Warnock, 2012. "Capital Flow Waves: Surges, Stops, Flight, and Retrenchment,” NBER Working Paper No. 17351. 
Goldberg, Linda S. and Signe Krogstrup, 2018. "International Capital Flow Pressures," NBER Working Paper No. 24286.

Hansen, Niels-Jakob and Signe Krogstrup, 2019. Capital Flows and Global Factors in Korea: An Investor Base Perspective. Unpublished Manuscript, International Monetary Fund.

Hyun Song Shin, 2012 “Global Banking Glut and Loan Risk Premium,” IMF Economic Review 60 (July 2012) 155-192.

International Monetary Fund, 2010. "Global Liquidity Expansion: Effects on "Receiving" Economies and Policy Response Options" Chapter 4 in Global Financial Stability Report, April 2010.

International Monetary Fund, 2013. "The yin and yang of capital flow management: balancing capital inflows with capital outflows" Chapter 4 in World Economic Outlook, October 2013.

International Monetary Fund, 2014a. "How do changes in the investor base and financial deepening affect emerging market economies?" Chapter 2 in Global Financial Stability Report, April 2014.

International Monetary Fund, 2014b. "Shadow Banking around the Globe: How Large, and How Risky?” Chapter 2 in Global Financial Stability Report, October 2014.

International Monetary Fund, 2015. "Rethinking Financial Deepening: Stability and Growth in Emerging Markets," IMF Staff Discussion Note, May 2015.

International Monetary Fund, 2016a. "Understanding the Slowdown of Capital Flows to Emerging Markets” Chapter 2 in World Economic Outlook, April 2016.

International Monetary Fund, 2016b. "Monetary Policy and the Rise of Nonbank Finance" Chapter 2 in Global Financial Stability Report, October 2016.

International Monetary Fund, 2017. "Financial Conditions and Growth at Risk" Chapter 3 in Global Financial Stability Report, October 2017.

Kiyotaki, Nobuhiro and John Moore, 1997. “Credit Cycles,” Journal of Political Economy Vol. 105, No. 2 pp. 211-248.

Klein, Michael and Jay Shambaugh, 2008. "The dynamics of exchange rate regimes: Fixes, floats, and flips," Journal of International Economics, Elsevier, vol. 75(1), pages 70-92, May. 
Krippner, Leo, 2016. "Documentation for measures of monetary policy,” July 2016.

https://www.rbnz.govt.nz/-

/media/ReserveBank/Files/Publications/Research/Additional\%20research/Leo\%20Krip pner/5892888.pdf

Krogstrup, Signe and Cedric Tille, 2018. "Foreign current funding and global factors," Unpublished manuscript, the Graduate Institute of Geneva.

Lane, Philip and Gian Maria Milesi-Ferretti, 2001. "Long-term Capital Movements," NBER Macroeconomics Annual 2001, edited by Ben S. Bernanke and Kenneth S. Rogoff. MIT Press.

Levchenko, Andrei A. and Paolo Mauro, 2007. "Do some forms of financial flows help protect against 'sudden stops'?” World Bank Economic Review, 21(3), pp. 389-411.

Magud, Nicolas, 2018. "Discussion of Capital Flows: The Role of Bank and Nonbank Balance Sheet," discussion presentation at Research Department workshop on Too Many Objectives or Too Few Instruments? Economic Policy Challenges Ten Years After the Crisis. March 22, 2018.

Milesi-Ferretti, Gian Maria and Cédric Tille, 2011. "The great retrenchment: international capital flows during the global financial crisis," Economic Policy, 26 (2011), pp. 289346.

Miranda-Agrippino, Silvia and Hélène Rey, 2018. "US Monetary Policy and the Global Financial Cycle,” NBER Working Paper 21722.

Passari, Evgenia, and Hélène Rey, 2015. "Financial Flows and the International Monetary System.” The Economic Journal 125.584 (2015): 675-698.

Ree, Jack Joo K., Kyoungsoo Yoon, and Hail Park, 2012. "FX Funding Risks and Exchange Rate Volatility—Korea's Case," IMF Working Paper WP/12/268.

Ryoo, Sangdai, Taeyong Kwon and Hyejin Lee1, 2013. "Foreign exchange market developments and intervention in Korea," BIS Papers No 73, pp.205-213.

Scheubel, Beatrice, Livio Stracca and Cedric Tille, 2018. "Taming the Global Financial Cycle: What Role for the Global Financial Safety Net?” Unpublished mimeo. 


\section{APPENDIX}

\section{A. Data Appendix}

Table A1. Country Coverage and Data Availability

\begin{tabular}{|c|c|c|c|c|c|c|}
\hline \multirow{3}{*}{$\begin{array}{c}\text { ifscode } \\
111 \\
\end{array}$} & \multirow{2}{*}{\multicolumn{2}{|c|}{ country }} & \multirow{3}{*}{\begin{tabular}{|c|} 
Banks (ODC) \\
200104 \\
\end{tabular}} & \multicolumn{2}{|c|}{ Non-banks (OFC) } & \multirow{3}{*}{$\begin{array}{c}\text { Frequency } \\
\mathrm{Q}\end{array}$} \\
\hline & & & & \multirow{2}{*}{$\begin{array}{c}\text { Cross-border } \\
2001 Q 4\end{array}$} & \multirow{2}{*}{$\begin{array}{c}\text { Domestic } \\
2001 Q 4 \\
\end{array}$} & \\
\hline & United States & US & & & & \\
\hline 144 & Sweden & SE & $2001 \mathrm{M} 12$ & $2001 Q 4$ & $2001 Q 4$ & ODC: M; OFC: Q \\
\hline 158 & Japan & $J P$ & $2001 \mathrm{M} 12$ & $2001 Q 4$ & $2001 Q 4$ & ODC: M; OFC: Q \\
\hline 186 & Turkey & TR & $2002 \mathrm{M} 12$ & $2008 Q 1$ & 2008Q1 & ODC: M; OFC: Q \\
\hline 199 & South Africa & ZA & $2001 \mathrm{M} 12$ & $2001 \mathrm{M} 12$ & $2001 \mathrm{M} 12$ & $M$ \\
\hline 218 & Bolivia & BO & $2001 \mathrm{M} 12$ & 2005M1 & 2005M1 & $\mathrm{M}$ \\
\hline 223 & Brazil & BR & $2001 \mathrm{M} 12$ & $2001 \mathrm{M} 12$ & $2001 \mathrm{M} 12$ & $\mathrm{M}$ \\
\hline 228 & Chile & $\mathrm{CL}$ & $2001 \mathrm{M} 12$ & $2001 \mathrm{M} 12$ & $2001 \mathrm{M} 12$ & $\mathrm{M}$ \\
\hline 233 & Colombia & $\mathrm{CO}$ & $2001 \mathrm{M} 12$ & $2001 \mathrm{M} 12$ & $2001 \mathrm{M} 12$ & $\mathrm{M}$ \\
\hline 243 & Dominican Republic & DO & 2001M12 & $2004 \mathrm{M} 9$ & $2004 \mathrm{M} 9$ & $\mathrm{M}$ \\
\hline 248 & Ecuador & EC & $2002 \mathrm{M} 7$ & 2002M7-2012M6 & 2002M7-2012M6 & $\mathrm{M}$ \\
\hline 253 & El Salvador & SV & $2001 \mathrm{M} 12$ & $2001 \mathrm{M} 12$ & $2001 \mathrm{M} 12$ & $\mathrm{M}$ \\
\hline 268 & Honduras & $\mathrm{HN}$ & $2001 \mathrm{M} 12$ & $2001 \mathrm{M} 12$ & $2001 \mathrm{M} 12$ & $\mathrm{M}$ \\
\hline 536 & Indonesia & ID & $2001 \mathrm{M} 12$ & 2009M11 & 2009M11 & $\mathrm{M}$ \\
\hline 578 & Thailand & $\mathrm{TH}$ & 2001M12 & 2007M1 & 2007M1 & $\mathrm{M}$ \\
\hline 911 & Armenia, Republic of & AM & $2001 \mathrm{M} 12$ & 2009M1 & 2009M1 & $\mathrm{M}$ \\
\hline 913 & Belarus & BY & $2001 \mathrm{M} 12$ & $2007 Q 4$ & $2007 Q 4$ & ODC: M; OFC: Q \\
\hline 914 & Albania & $\mathrm{AL}$ & $2002 \mathrm{M} 12$ & $2009 Q 1$ & 2009Q1 & ODC: M; OFC: Q \\
\hline 915 & Gerogia & GE & $2001 \mathrm{M} 12$ & $2012 Q 4$ & $2012 Q 4$ & ODC: M; OFC: Q \\
\hline 916 & Kazakhstan & $\mathrm{KZ}$ & 2003M12 & 2015Q1 & $2015 Q 1$ & ODC: M; OFC: Q \\
\hline 921 & Moldova & $\mathrm{MD}$ & $2001 \mathrm{M} 12$ & $2010 Q 2$ & $2010 Q 2$ & ODC: M; OFC: Q \\
\hline 926 & Ukraine & UA & $2001 \mathrm{M} 12$ & $2008 Q 4$ & $2008 Q 4$ & ODC: M; OFC: Q \\
\hline 962 & Macedonia & MK & 2003M11 & $2012 Q 1$ & 2012Q1 & ODC: M; OFC: Q \\
\hline 968 & Romania & RO & $2001 \mathrm{M} 12$ & 2012Q1 & 2012Q1 & ODC: M; OFC: Q \\
\hline
\end{tabular}




\section{B. Data Description}

Table A2. Source Data and Description of Variables

\begin{tabular}{|c|c|c|c|}
\hline Variable & Definition & Description & Source \\
\hline $\begin{array}{l}\text { Net capital } \\
\text { inflows }\end{array}$ & $\begin{array}{l}\text { Total net } \\
\text { nonofficial } \\
\text { flows/(private } \\
\text { external assets }+ \\
\text { private external } \\
\text { liabilities) }\end{array}$ & \multirow{4}{*}{$\begin{array}{l}* \text { Net capital inflows }=2 * \text { NCAPFLP/ (private } \\
\text { external assets }+ \text { private external liabilities) } \\
* \text { Gross non-resident inflows }=\text { ICAPFLP/ private } \\
\text { external liabilities } \\
* \text { Gross resident inflows }=(-1) * \text { OCAPFLP / private } \\
\text { external assets } \\
\text { *Net bank inflows }=2 * \text { NOTHFB/(private external } \\
\text { assets + private external liabilities) } \\
\text { NCAPFLP is total net nonofficial inflows; ICAPFLP } \\
\text { total gross nonofficial inflows; OCAPFLP total gross } \\
\text { nonofficial outflows; and NOTHFB is other inflows to } \\
\text { banks minus other outflows to banks. }\end{array}$} & \multirow{4}{*}{$\begin{array}{l}\text { IMF, } \\
\text { International } \\
\text { Investment } \\
\text { Positions (IIP) } \\
\text { and Financial } \\
\text { Flows Analytics } \\
\text { Database } \\
\text { (FFA). }\end{array}$} \\
\hline $\begin{array}{l}\text { Gross non- } \\
\text { resident } \\
\text { inflows }\end{array}$ & $\begin{array}{l}\text { Total gross } \\
\text { nonofficial inflows/ } \\
\text { private external } \\
\text { liabilities }\end{array}$ & & \\
\hline $\begin{array}{l}\text { Gross } \\
\text { resident } \\
\text { inflows }\end{array}$ & $\begin{array}{l}\text { Total gross } \\
\text { nonofficial } \\
\text { outflows /private } \\
\text { external assets }\end{array}$ & & \\
\hline $\begin{array}{l}\text { Net bank } \\
\text { inflows }\end{array}$ & $\begin{array}{l}\text { Net other inflows to } \\
\text { banks/(private } \\
\text { external assets }+ \\
\text { private external } \\
\text { liabilities) }\end{array}$ & & \\
\hline$E M P$ & $\begin{array}{l}\text { Goldberg and } \\
\text { Krogstrup EMP } \\
\text { index }\end{array}$ & Monthly. & $\begin{array}{l}\text { Goldberg and } \\
\text { Krogstrup } \\
\text { [2018]. }\end{array}$ \\
\hline$N E T E X P_{F C}$ & $\begin{array}{l}\text { Net exposure for } \\
\text { total financial } \\
\text { corporations }\end{array}$ & $\begin{array}{l}\text { Quarterly. Net exposure for total financial institutions } \\
=\text { (total financial institutions external assets - total } \\
\text { financial institutions external liabilities) / total } \\
\text { financial institutions total assets. }\end{array}$ & $\begin{array}{l}\text { IMF } \\
\text { Standardized } \\
\text { Report Form } \\
\text { (SRF). }\end{array}$ \\
\hline$N E T E X P_{B}$ & $\begin{array}{l}\text { Net exposure for } \\
\text { banks }\end{array}$ & $\begin{array}{l}\text { Quarterly. Net exposure for banks = (Banks external } \\
\text { assets - Banks external liabilities }) \text { / Banks total assets. }\end{array}$ & $\begin{array}{l}\text { IMF } \\
\text { Standardized } \\
\text { Report Form } \\
\text { (SRF). }\end{array}$ \\
\hline$N E T E X P_{N B}$ & $\begin{array}{l}\text { Net exposure for } \\
\text { nonbanks }\end{array}$ & $\begin{array}{l}\text { Quarterly. Net exposure for nonbanks }=(\text { Nonbanks } \\
\text { external assets }- \text { Nonbanks external liabilities }) / \\
\text { Nonbanks total assets. }\end{array}$ & $\begin{array}{l}\text { IMF } \\
\text { Standardized } \\
\text { Report Form } \\
\text { (SRF). }\end{array}$ \\
\hline VIX & $\begin{array}{l}\text { CBOE Volatility } \\
\text { index }\end{array}$ & $\begin{array}{l}\text { End of period, monthly. Extended backwards in time } \\
\text { by the VXO from } 1986 \mathrm{~m} 1 \text { to } 1989 \mathrm{~m} 12 \text {. }\end{array}$ & $\begin{array}{l}\text { Chicago Board } \\
\text { Options } \\
\text { Exchange. }\end{array}$ \\
\hline$i$ & $\begin{array}{l}\text { Monetary policy or } \\
\text { short- } \\
\text { term rate }\end{array}$ & $\begin{array}{l}\text { In percentage points, end of period, monthly. } \\
\text { Constructed as IFS policy rate line } 60 \text { if available, } \\
\text { else policy rate from national central bank if available, } \\
\text { else } 3 \text {-month money market interest rate from IFS } \\
\text { (line } 60 \mathrm{~b} \text { ) if available, else short-term treasury bond } \\
\text { rate (IFS line 60c) if available. For countries that have } \\
\text { introduced negative policy interest rates, the relevant } \\
\text { policy rate prior to the introduction of a negative rate } \\
\text { is merged with the relevant rate post introduction for } \\
\text { Japan. }\end{array}$ & $\begin{array}{l}\text { IMF } \\
\text { International } \\
\text { Financial } \\
\text { Statistics or } \\
\text { national Central } \\
\text { Banks. }\end{array}$ \\
\hline$i_{S R}^{*}$ & $\begin{array}{l}\text { Shadow policy rate } \\
\text { in US, EU, Japan } \\
\text { and UK }\end{array}$ & In percentage points, end of period, monthly. & $\begin{array}{l}\text { Krippner } \\
\text { [2016]. }\end{array}$ \\
\hline
\end{tabular}




\begin{tabular}{|c|c|c|c|}
\hline findepth & $\begin{array}{l}\text { Financial depth for } \\
\text { total }\end{array}$ & $\begin{array}{l}\text { Quarterly. Financial depth for total }=(\text { Bank domestic } \\
\text { assets + Nonbank domestic assets }) / \text { GDP }\end{array}$ & $\begin{array}{l}\text { IMF } \\
\text { Standardized } \\
\text { Report Form } \\
\text { (SRF). }\end{array}$ \\
\hline$N F A$ & Net financial assets & $\begin{array}{l}\text { Quarterly. NFA=2*(external assets }- \text { external } \\
\text { liabilities }) /(\text { external assets }+ \text { external liabilities })\end{array}$ & $\begin{array}{l}\text { IMF } \\
\text { International } \\
\text { Investment } \\
\text { Positions (IIP). }\end{array}$ \\
\hline peg & $\begin{array}{l}\text { Standard } \\
\text { Shambaugh } \\
\text { measure of pegs }\end{array}$ & $1=$ peg, $0=$ nonpeg, yearly. & $\begin{array}{l}\text { Klein and } \\
\text { Shambaugh } \\
{[2008]}\end{array}$ \\
\hline kaopen & Chinn-Ito index & Yearly. & $\begin{array}{l}\text { Aizenman, } \\
\text { Chinn, Ito } \\
\text { [2015] }\end{array}$ \\
\hline$d B \_F A$ & $\begin{array}{l}\text { Change in banks' } \\
\text { foreign asset } \\
\text { position. }\end{array}$ & $\begin{array}{l}\text { Quarterly. First difference of B_FA; B_FA= banks' } \\
\text { foreign asset positions over the sum of banks' and } \\
\text { nonbanks' total asset positions. }\end{array}$ & $\begin{array}{l}\text { IMF } \\
\text { Standardized } \\
\text { Report Form } \\
\text { (SRF). }\end{array}$ \\
\hline$d N B \_F A$ & $\begin{array}{l}\text { Change in } \\
\text { nonbanks' foreign } \\
\text { asset position. }\end{array}$ & $\begin{array}{l}\text { Quarterly. First difference of NB_FA; } \\
\text { NB_FA = nonbanks' foreign asset positions over the } \\
\text { sum of banks' and nonbanks' total asset positions. }\end{array}$ & $\begin{array}{l}\text { IMF } \\
\text { Standardized } \\
\text { Report Form } \\
\text { (SRF). }\end{array}$ \\
\hline$d e^{e u r}-u s d$ & $\begin{array}{l}\text { Change in exchange } \\
\text { rate (euro per } \\
\text { USD). }\end{array}$ & $\begin{array}{l}\text { Quarterly. Defined as the change between end of last } \\
\text { quarter and end of current quarter, divided by the } \\
\text { change in the end-of-last quarter exchange rate. }\end{array}$ & $\begin{array}{l}\text { IMF Global } \\
\text { Assumptions } \\
\text { Data (GAS). }\end{array}$ \\
\hline$d e^{i \_u s d}$ & $\begin{array}{l}\text { Change in exchange } \\
\text { rate (local currency } \\
\text { per USD). }\end{array}$ & $\begin{array}{l}\text { Quarterly. Defined as the change between end of last } \\
\text { quarter and end of current quarter, divided by the } \\
\text { change in the end-of-last quarter exchange rate. }\end{array}$ & $\begin{array}{l}\text { IMF Global } \\
\text { Assumptions } \\
\text { Data (GAS). }\end{array}$ \\
\hline
\end{tabular}




\title{
C. Financial Depth
}

Financial depth is calculated using the size of domestic as well as external positions in the balance sheet. Financial depth based on total balance sheet is almost similar (and identical) to financial depths calculated using domestic positions. This implies that developments of the domestic financial system helped financial deepening. We also provide two charts of relationships between the bank size in the financial system and financial depth, using two alternative (domestic and external positions) measures below.

Figure A1. Financial Depth and Balance Sheet

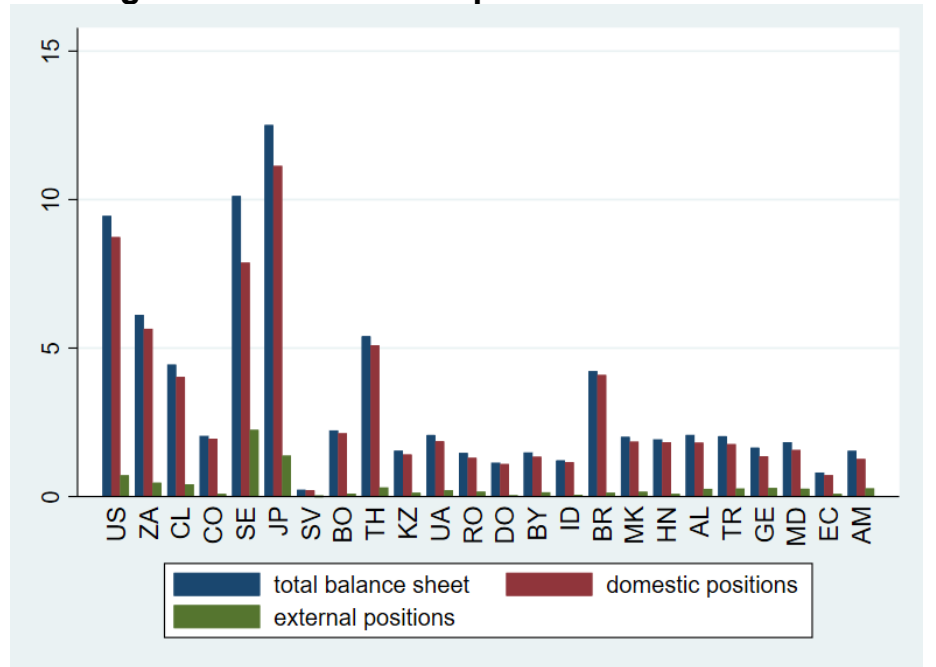

\begin{abstract}
Note: The chart is based on the average of the most recent five-year observations. Countries are sorted by share of banks in total assets (Figure 2, for comparability). Financial depth for each of total, domestic, and external, is calculated as follows: Financial depth for total $=($ Bank total assets + Bank total liabilities + Nonbank total assets + Nonbank total liabilities) / GDP; Financial depth for domestic = (Bank domestic assets + Bank domestic liabilities + Nonbank domestic assets + Nonbank domestic liabilities) / GDP; Financial depth for external $=($ Bank external assets + Bank external liabilities + Nonbank external assets + Nonbank external liabilities) / GDP. All bank and nonbank balance sheet data are from the SRF dataset.
\end{abstract}

Figure A2. Bank Share and Financial Depth

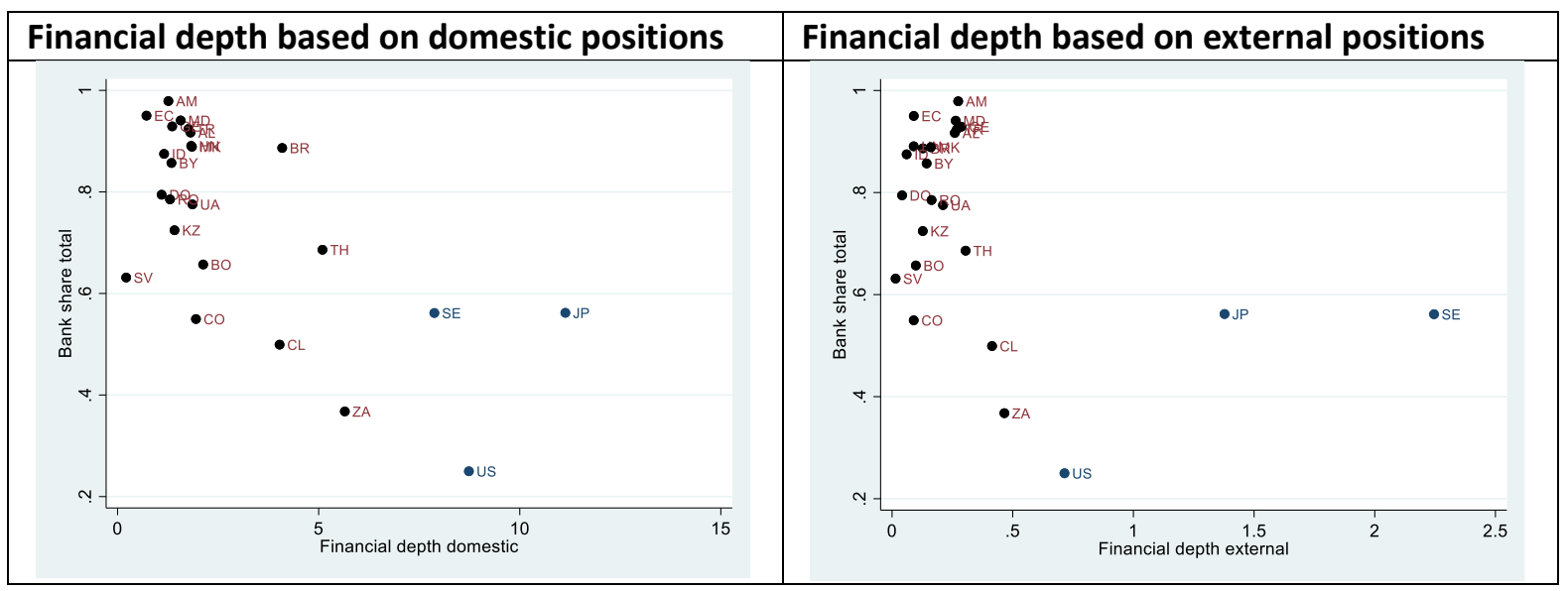

Note: The chart is based on the average of the most recent five-year observations. Financial depth (Figure A1) and bank share (Figure 2) are plotted together, using financial depth measures based on domestic as well as external positions. 


\section{Net Foreign Exposure by Financial Institutions}

The chart below shows net foreign positions by types of financial institutions. In general, banks are more balanced where nonbanks share is larger, and nonbanks have larger external asset share in their balance sheets. This reflects that banks often fund externally and lend domestically, whereas nonbanks are often domestically funded but partly invest abroad. The pattern reversed towards the right of the chart, where banks dominate in the financial system.

Figure A3. Net Foreign Exposure

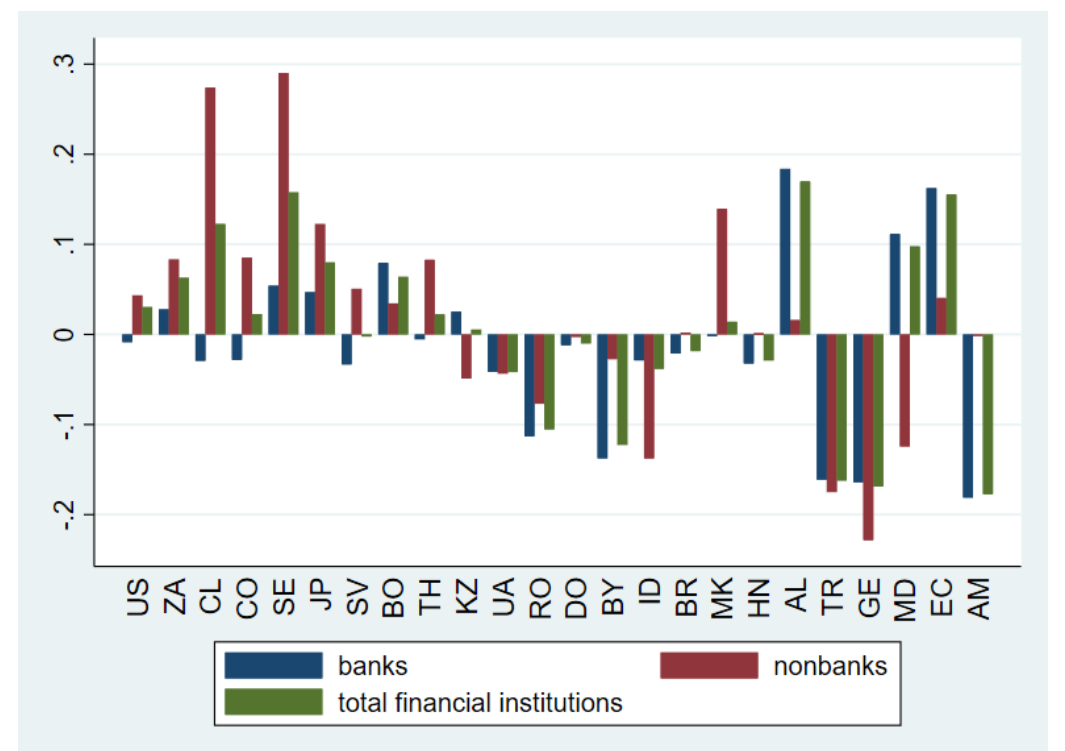

Note: charts are based on the average of the most recent five-year observations. The net foreign exposure of banks, nonbanks and total, is measured as followed: Net exposure for banks = (Banks external assets - Banks external liabilities) / Banks total assets; Net exposure for nonbanks = (Nonbanks external assets - Nonbanks external liabilities) / Nonbanks total assets; Net exposure for total financial institutions = (total financial institutions external assets - total financial institutions external liabilities) / total financial institutions total assets. All balance sheet data are from the SRF dataset. Countries are sorted by share of banks in total assets, as in Figure 2, for comparability. 


\section{E. Robustness Checks}

Table A3. Robustness: Total Financial Institutions Exposures on Capital Flows, 2002Q1-2017Q4

\begin{tabular}{|c|c|c|c|c|c|c|c|c|}
\hline \multirow{2}{*}{$\overline{d l o g}(\mathrm{VIX})$} & 1 & II & III & IV & $\mathrm{V}$ & $\mathrm{VI}$ & VII & VIII \\
\hline & $\begin{array}{l}-0.003 \\
(0.003)\end{array}$ & $\begin{array}{l}-0.003 \\
(0.003)\end{array}$ & $\begin{array}{l}-0.000 \\
(0.004)\end{array}$ & $\begin{array}{l}-0.004 \\
(0.004)\end{array}$ & $\begin{array}{c}-0.007^{* *} \\
(0.003)\end{array}$ & $\begin{array}{l}-0.004^{*} \\
(0.002)\end{array}$ & $\begin{array}{l}-0.003 \\
(0.003)\end{array}$ & $\begin{array}{l}-0.005^{*} \\
(0.003)\end{array}$ \\
\hline dlog(VIX)_NETEXP $P_{\mathrm{FC}, \mathrm{t}-1}$ & $\begin{array}{l}0.068^{*} \\
(0.035)\end{array}$ & $\begin{array}{c}0.056 \\
(0.044)\end{array}$ & $\begin{array}{l}0.079 * * \\
(0.037)\end{array}$ & $\begin{array}{c}0.077 \\
(0.050)\end{array}$ & $\begin{array}{c}0.040 \\
(0.032)\end{array}$ & $\begin{array}{l}0.065^{*} \\
(0.038)\end{array}$ & $\begin{array}{l}0.089 * * \\
(0.036)\end{array}$ & $\begin{array}{l}0.071^{* *} \\
(0.028)\end{array}$ \\
\hline NETEXP $_{\mathrm{FC}, \mathrm{t}-1}$ & $\begin{array}{c}0.069 \\
(0.047)\end{array}$ & $\begin{array}{c}0.060 \\
(0.048)\end{array}$ & $\begin{array}{c}0.070 \\
(0.047)\end{array}$ & $\begin{array}{c}0.065 \\
(0.043)\end{array}$ & $\begin{array}{c}0.076 \\
(0.046)\end{array}$ & $\begin{array}{c}0.070 \\
(0.046)\end{array}$ & $\begin{array}{c}0.075 \\
(0.052)\end{array}$ & $\begin{array}{c}0.056 \\
(0.040)\end{array}$ \\
\hline$d\left(i^{*}\right)$ & $\begin{array}{c}0.005 \\
(0.004)\end{array}$ & $\begin{array}{c}0.005 \\
(0.004)\end{array}$ & $\begin{array}{c}0.005 \\
(0.004)\end{array}$ & $\begin{array}{c}0.005 \\
(0.004)\end{array}$ & $\begin{array}{c}0.005 \\
(0.004)\end{array}$ & $\begin{array}{c}0.005 \\
(0.004)\end{array}$ & $\begin{array}{c}0.005 \\
(0.004)\end{array}$ & $\begin{array}{c}0.004 \\
(0.004)\end{array}$ \\
\hline$d\left(i^{*}{ }_{S R}\right)$ & $\begin{array}{l}-0.006 \\
(0.004)\end{array}$ & $\begin{array}{l}-0.006 \\
(0.005)\end{array}$ & $\begin{array}{l}-0.005 \\
(0.004)\end{array}$ & $\begin{array}{l}-0.006 \\
(0.004)\end{array}$ & $\begin{array}{l}-0.006 \\
(0.005)\end{array}$ & $\begin{array}{l}-0.006 \\
(0.004)\end{array}$ & $\begin{array}{l}-0.007 \\
(0.005)\end{array}$ & $\begin{array}{l}-0.005 \\
(0.004)\end{array}$ \\
\hline findepth $_{\mathrm{t}-1}$ & & & $\begin{array}{l}-0.002 \\
(0.005)\end{array}$ & & & & & \\
\hline $\operatorname{dlog}(\mathrm{VIX})_{\text {_findepth }} \mathrm{t}_{\mathrm{t}-1}$ & & & $\begin{array}{l}-0.002 \\
(0.002)\end{array}$ & & & & & \\
\hline dlog(VIX)_NFA $t_{t-1}$ & & & & $\begin{array}{l}-0.002 \\
(0.008)\end{array}$ & & & & \\
\hline$N F A_{t-1}$ & & & & $\begin{array}{c}0.001 \\
(0.010)\end{array}$ & & & & \\
\hline dlog(VIX)_peg & & & & & $\begin{array}{l}0.012 * \\
(0.006)\end{array}$ & & & \\
\hline peg & & & & & $\begin{array}{l}-0.006 \\
(0.007)\end{array}$ & & & \\
\hline dlog(VIX)_kaopen & & & & & & $\begin{array}{c}0.001 \\
(0.002)\end{array}$ & & \\
\hline kaopen & & & & & & $\begin{array}{l}-0.002 \\
(0.005)\end{array}$ & & \\
\hline R_squared & 0.02 & 0.02 & 0.02 & 0.02 & 0.02 & 0.02 & 0.02 & 0.01 \\
\hline Adj. R_squared & 0.01 & 0.01 & 0.01 & 0.01 & 0.02 & 0.01 & 0.02 & 0.01 \\
\hline Nobs & 987 & 919 & 987 & 986 & 967 & 987 & 805 & 959 \\
\hline No.cross sections & 24 & 21 & 24 & 24 & 23 & 24 & 21 & 24 \\
\hline Fixed effects & Yes & Yes & Yes & Yes & Yes & Yes & Yes & Yes \\
\hline
\end{tabular}

Note: Column I is identical to Table 2 (a), the first column regression. Column II excludes oil countries Armenia, Georgia and Kazakhstan. Column VII excludes Advanced Economies from the sample. Column VIII excludes the observations specific to the Global Financial Crisis. Numbers in parentheses are standard errors. Asterisks *, ** and *** indicate significance at the 10,5 percent and 1 percent levels, respectively, using robust clustered standard errors and covariances. 
Table A4. Robustness: Bank Foreign Exposures on Capital Flows, 2002Q1-2017Q4

\begin{tabular}{|c|c|c|c|c|c|c|c|c|}
\hline & 1 & II & III & IV & $\mathrm{V}$ & VI & VII & VIII \\
\hline \multirow[t]{2}{*}{$\operatorname{dlog}(\mathrm{VIX})$} & -0.002 & -0.001 & -0.001 & -0.001 & $-0.006 *$ & -0.003 & -0.002 & -0.004 \\
\hline & $(0.003)$ & $(0.003)$ & $(0.005)$ & $(0.003)$ & $(0.003)$ & $(0.002)$ & $(0.003)$ & $(0.003)$ \\
\hline \multirow[t]{2}{*}{ dlog(VIX)_NETEXP $P_{B, t-1}$} & 0.063 & 0.048 & 0.066 & 0.061 & 0.019 & 0.065 & 0.069 & 0.060 \\
\hline & $(0.041)$ & $(0.050)$ & $(0.042)$ & $(0.051)$ & $(0.043)$ & $(0.043)$ & $(0.043)$ & $(0.038)$ \\
\hline \multirow[t]{2}{*}{ NETEXP $_{B, t-1}$} & 0.072 & 0.064 & 0.073 & 0.067 & 0.073 & 0.076 & 0.077 & 0.059 \\
\hline & $(0.045)$ & $(0.046)$ & $(0.046)$ & $(0.042)$ & $(0.045)$ & $(0.045)$ & $(0.053)$ & $(0.038)$ \\
\hline \multirow[t]{2}{*}{$d\left(i^{*}\right)$} & 0.005 & 0.005 & 0.005 & 0.005 & 0.005 & 0.005 & 0.005 & 0.004 \\
\hline & $(0.004)$ & $(0.004)$ & $(0.004)$ & $(0.004)$ & $(0.004)$ & $(0.004)$ & $(0.004)$ & $(0.004)$ \\
\hline \multirow[t]{2}{*}{$d\left(i{ }_{S R}\right)$} & -0.006 & -0.006 & -0.005 & -0.006 & -0.006 & -0.006 & -0.007 & -0.005 \\
\hline & $(0.004)$ & $(0.005)$ & $(0.004)$ & $(0.004)$ & $(0.005)$ & $(0.004)$ & $(0.005)$ & $(0.004)$ \\
\hline \multirow[t]{2}{*}{ findepth $_{\mathrm{t}-1}$} & & & -0.003 & & & & & \\
\hline & & & $(0.005)$ & & & & & \\
\hline \multirow[t]{2}{*}{ dlog(VIX)_findepth $\mathrm{t}_{\mathrm{t}-1}$} & & & -0.001 & & & & & \\
\hline & & & $(0.002)$ & & & & & \\
\hline \multirow[t]{2}{*}{ dlog(VIX)_NFA $A_{t-1}$} & & & & 0.001 & & & & \\
\hline & & & & $(0.007)$ & & & & \\
\hline \multirow[t]{2}{*}{$\mathrm{NFA}_{\mathrm{t}-1}$} & & & & 0.003 & & & & \\
\hline & & & & (0.010) & & & & \\
\hline \multirow[t]{2}{*}{ dlog(VIX)_peg } & & & & & $0.011^{*}$ & & & \\
\hline & & & & & $(0.006)$ & & & \\
\hline \multirow[t]{2}{*}{ peg } & & & & & -0.005 & & & \\
\hline & & & & & $(0.007)$ & & & \\
\hline \multirow[t]{2}{*}{ dlog(VIX)_kaopen } & & & & & & 0.002 & & \\
\hline & & & & & & $(0.002)$ & & \\
\hline \multirow[t]{2}{*}{ kaopen } & & & & & & -0.003 & & \\
\hline & & & & & & $(0.005)$ & & \\
\hline R_squared & 0.02 & 0.02 & 0.02 & 0.02 & 0.02 & 0.02 & 0.02 & 0.01 \\
\hline Adj. R_squared & 0.01 & 0.01 & 0.01 & 0.01 & 0.02 & 0.02 & 0.01 & 0.01 \\
\hline Nobs & 988 & 919 & 988 & 987 & 968 & 988 & 806 & 960 \\
\hline No.cross sections & 24 & 21 & 24 & 24 & 23 & 24 & 21 & 24 \\
\hline Fixed effects & Yes & Yes & Yes & Yes & Yes & Yes & Yes & Yes \\
\hline
\end{tabular}

Note: Column I is identical to Table 2 (b), the first column regression. Column II excludes oil countries Armenia, Georgia and Kazakhstan. Column VII excludes Advanced Economies from the sample. Column VIII excludes the observations specific to the Global Financial Crisis. Numbers in parentheses are standard errors. Asterisks * ${ }^{* *}$ and ${ }^{* * *}$ indicate significance at the 10,5 percent and 1 percent levels, respectively, using robust clustered standard errors and covariances. 
Table A5. Robustness: Nonbank Foreign Exposures on Capital Flows, 2006Q4-2017Q4

\begin{tabular}{|c|c|c|c|c|c|c|c|c|}
\hline & 1 & II & III & IV & $\mathrm{V}$ & $\mathrm{VI}$ & VII & VIII \\
\hline \multirow[t]{2}{*}{ dlog(VIX) } & -0.003 & -0.002 & 0.002 & -0.003 & $-0.007^{* *}$ & -0.003 & -0.002 & -0.004 \\
\hline & $(0.003)$ & $(0.003)$ & $(0.005)$ & $(0.003)$ & $(0.003)$ & $(0.002)$ & $(0.003)$ & (0.003) \\
\hline \multirow[t]{2}{*}{ dlog(VIX)_NETEXP NB,,$-1_{1}$} & $0.050^{* *}$ & $0.048^{*}$ & $0.060^{* *}$ & $0.052^{*}$ & $0.045^{* *}$ & $0.048^{* *}$ & $0.079 * * *$ & $0.046^{*}$ \\
\hline & $(0.022)$ & $(0.024)$ & $(0.025)$ & $(0.026)$ & $(0.017)$ & $(0.021)$ & $(0.021)$ & (0.023) \\
\hline \multirow[t]{2}{*}{ NETEXP $_{N B, t-1}$} & -0.023 & -0.015 & -0.008 & -0.023 & 0.011 & -0.023 & -0.022 & -0.044 \\
\hline & $(0.043)$ & $(0.043)$ & $(0.048)$ & (0.044) & $(0.030)$ & $(0.042)$ & (0.044) & (0.041) \\
\hline \multirow[t]{2}{*}{$d\left(i^{*}\right)$} & 0.005 & 0.006 & 0.005 & 0.005 & 0.005 & 0.005 & 0.005 & 0.004 \\
\hline & $(0.004)$ & $(0.004)$ & $(0.004)$ & (0.004) & $(0.004)$ & $(0.004)$ & (0.004) & (0.004) \\
\hline \multirow[t]{2}{*}{$d\left(i^{*}{ }_{S R}\right)$} & -0.006 & -0.006 & -0.001 & -0.006 & -0.007 & -0.006 & -0.008 & -0.006 \\
\hline & $(0.005)$ & $(0.005)$ & (0.004) & $(0.005)$ & $(0.005)$ & $(0.005)$ & $(0.006)$ & (0.005) \\
\hline findepth $_{\mathrm{t}-1}$ & & & $\begin{array}{c}-0.025^{* *} \\
(0.010)\end{array}$ & & & & & \\
\hline \multirow[t]{2}{*}{ dlog(VIX)_findepth $\mathrm{t}_{\mathrm{t}-1}$} & & & -0.003 & & & & & \\
\hline & & & $(0.002)$ & & & & & \\
\hline \multirow[t]{2}{*}{$\operatorname{dlog}(\mathrm{VIX}) \_N F A_{t-1}$} & & & & -0.001 & & & & \\
\hline & & & & $(0.007)$ & & & & \\
\hline \multirow[t]{2}{*}{$N F A_{t-1}$} & & & & 0.004 & & & & \\
\hline & & & & $(0.024)$ & & & & \\
\hline \multirow[t]{2}{*}{ dlog(VIX)_peg } & & & & & $0.013^{*}$ & & & \\
\hline & & & & & $(0.007)$ & & & \\
\hline \multirow[t]{2}{*}{ peg } & & & & & -0.003 & & & \\
\hline & & & & & $(0.007)$ & & & \\
\hline \multirow[t]{2}{*}{ dlog(VIX)_kaopen } & & & & & & 0.001 & & \\
\hline & & & & & & $(0.003)$ & & \\
\hline \multirow[t]{2}{*}{ kaopen } & & & & & & -0.001 & & \\
\hline & & & & & & $(0.005)$ & & \\
\hline R_squared & 0.02 & 0.02 & 0.04 & 0.02 & 0.02 & 0.02 & 0.02 & 0.02 \\
\hline Adj. R_squared & 0.01 & 0.01 & 0.03 & 0.01 & 0.01 & 0.01 & 0.01 & 0.01 \\
\hline Nobs & 825 & 757 & 825 & 825 & 805 & 825 & 699 & 797 \\
\hline No.cross sections & 24 & 21 & 24 & 24 & 23 & 24 & 21 & 24 \\
\hline Fixed effects & Yes & Yes & Yes & Yes & Yes & Yes & Yes & Yes \\
\hline
\end{tabular}

Note: Column II excludes oil countries Armenia, Georgia and Kazakhstan. Column VII excludes Advanced Economies from the sample. Column VIII excludes the observations specific to the Global Financial Crisis. Numbers in parentheses are standard errors. Asterisks * ${ }^{* *}$ and ${ }^{* * *}$ indicate significance at the 10, 5 percent and 1 percent levels, respectively, using robust clustered standard errors and covariances. 
Table A6. Robustness: Nonbank Foreign Exposures on Capital Flows, 2009Q3-2017Q4

\begin{tabular}{|c|c|c|c|c|c|c|c|c|}
\hline & 1 & II & III & IV & V & VI & VII & VIII \\
\hline \multirow[t]{2}{*}{ dlog(VIX) } & $-0.006 *$ & $-0.007^{*}$ & -0.003 & -0.006 & $-0.007^{*}$ & $-0.006^{*}$ & -0.005 & $-0.006 *$ \\
\hline & $(0.003)$ & $(0.003)$ & $(0.005)$ & $(0.004)$ & $(0.004)$ & $(0.003)$ & $(0.003)$ & $(0.003)$ \\
\hline \multirow[t]{2}{*}{ dlog(VIX)_NETEXP ${ }_{\mathrm{NB}, \mathrm{t}-1}$} & $0.054^{* *}$ & $0.055^{* *}$ & $0.062 * * *$ & $0.056^{* *}$ & $0.053^{* *}$ & $0.048^{* *}$ & $0.071^{* * *}$ & $0.054^{* *}$ \\
\hline & $(0.021)$ & $(0.022)$ & $(0.020)$ & $(0.025)$ & $(0.021)$ & $(0.022)$ & (0.017) & $(0.021)$ \\
\hline \multirow[t]{2}{*}{ NETEXP $_{\mathrm{NB}, \mathrm{t}-1}$} & -0.003 & 0.011 & 0.023 & -0.003 & -0.000 & -0.002 & -0.002 & -0.003 \\
\hline & (0.031) & $(0.032)$ & $(0.033)$ & $(0.029)$ & $(0.033)$ & $(0.030)$ & $(0.031)$ & (0.031) \\
\hline \multirow[t]{2}{*}{$d\left(i^{*}\right)$} & 0.003 & 0.003 & 0.003 & 0.003 & 0.003 & 0.003 & 0.003 & 0.003 \\
\hline & (0.005) & $(0.005)$ & $(0.004)$ & $(0.005)$ & (0.005) & $(0.005)$ & (0.005) & $(0.005)$ \\
\hline \multirow[t]{2}{*}{$d\left(i^{*}{ }_{S R}\right)$} & -0.003 & -0.003 & 0.004 & -0.003 & -0.003 & -0.002 & -0.004 & -0.003 \\
\hline & (0.004) & $(0.005)$ & $(0.004)$ & $(0.004)$ & $(0.005)$ & $(0.004)$ & $(0.005)$ & (0.004) \\
\hline \multirow[t]{2}{*}{ findepth $_{\mathrm{t}-1}$} & & & $-0.044 * * *$ & & & & & \\
\hline & & & $(0.012)$ & & & & & \\
\hline \multirow[t]{2}{*}{ dlog(VIX)_findepth ${ }_{t-1}$} & & & -0.000 & & & & & \\
\hline & & & $(0.002)$ & & & & & \\
\hline \multirow[t]{2}{*}{ dlog(VIX)_NFA $A_{t-1}$} & & & & -0.001 & & & & \\
\hline & & & & $(0.008)$ & & & & \\
\hline \multirow[t]{2}{*}{$\mathrm{NFA}_{\mathrm{t}-1}$} & & & & -0.001 & & & & \\
\hline & & & & $(0.021)$ & & & & \\
\hline \multirow[t]{2}{*}{ dlog(VIX)_peg } & & & & & 0.004 & & & \\
\hline & & & & & $(0.006)$ & & & \\
\hline \multirow[t]{2}{*}{ peg } & & & & & -0.001 & & & \\
\hline & & & & & $(0.008)$ & & & \\
\hline \multirow[t]{2}{*}{ dlog(VIX)_kaopen } & & & & & & 0.002 & & \\
\hline & & & & & & $(0.002)$ & & \\
\hline \multirow[t]{2}{*}{ kaopen } & & & & & & 0.004 & & \\
\hline & & & & & & $(0.005)$ & & \\
\hline R_squared & 0.01 & 0.01 & 0.05 & 0.01 & 0.01 & 0.01 & 0.01 & 0.01 \\
\hline Adj. R_squared & 0.00 & 0.00 & 0.04 & -0.00 & 0.00 & 0.00 & 0.00 & 0.00 \\
\hline Nobs & 688 & 621 & 688 & 688 & 675 & 688 & 595 & 688 \\
\hline No.cross sections & 23 & 20 & 23 & 23 & 22 & 23 & 20 & 23 \\
\hline Fixed effects & Yes & Yes & Yes & Yes & Yes & Yes & Yes & Yes \\
\hline
\end{tabular}

Note: Column II excludes oil countries Armenia, Georgia and Kazakhstan. Column VII excludes Advanced Economies from the sample. Column VIII excludes the observations specific to the Global Financial Crisis. Numbers in parentheses are standard errors. Asterisks *, ${ }^{* *}$ and ${ }^{* * *}$ indicate significance at the 10, 5 percent and 1 percent levels, respectively, using robust clustered standard errors and covariances. 
Table A7. Panel Regression for EM Country Sample, 2002Q1-2017Q4

(a) Net exposure for total financial institutions

\begin{tabular}{lccccc}
\hline & $\begin{array}{c}\text { net capital } \\
\text { inflows }\end{array}$ & $\begin{array}{c}\text { net bank } \\
\text { inflows }\end{array}$ & $\begin{array}{c}\text { gross non- } \\
\text { resident inflows }\end{array}$ & $\begin{array}{c}\text { gross resident } \\
\text { inflows }\end{array}$ & EMP \\
\hline $\mathrm{d} \log (\mathrm{VIX})$ & -0.003 & 0.001 & $-0.010^{* * *}$ & $0.011^{* *}$ & $-0.044^{* *}$ \\
$\mathrm{~d} \log (\mathrm{VIX})$ NETEXP & $(0.003)$ & $(0.002)$ & $(0.003)$ & $(0.004)$ & $(0.016)$ \\
& $0.088^{* *}, \mathrm{t}-1$ & -0.020 & 0.036 & 0.039 & $0.296^{* *}$ \\
NETEXP & $(0.036)$ & $(0.038)$ & $(0.021)$ & $(0.046)$ & $(0.136)$ \\
& 0.074 & 0.037 & 0.017 & $0.061^{* *}$ & $0.202^{* *}$ \\
$\mathrm{~d}\left(\mathrm{i}^{*}\right)$ & $(0.052)$ & $(0.028)$ & $(0.049)$ & $(0.026)$ & $(0.087)$ \\
& 0.005 & -0.000 & $0.005^{*}$ & -0.002 & $-0.024^{* *}$ \\
$\mathrm{~d}\left(\mathrm{i}^{*}{ }_{\text {SR }}\right)$ & $(0.004)$ & $(0.002)$ & $(0.003)$ & $(0.001)$ & $(0.009)$ \\
& -0.007 & -0.000 & $-0.008^{*}$ & 0.002 & -0.019 \\
R_squared & $(0.005)$ & $(0.002)$ & $(0.004)$ & $(0.004)$ & $(0.025)$ \\
Adj. R_squared & 0.02 & 0.01 & 0.02 & 0.02 & 0.04 \\
Nobs & 0.01 & 0.01 & 0.01 & 0.01 & 0.03 \\
No.cross sections & 806 & 802 & 806 & 806 & 811 \\
Fixed effects & 21 & 21 & 21 & 21 & 20 \\
\hline
\end{tabular}

(b) Net exposure for banks

\begin{tabular}{lccccc}
\hline & $\begin{array}{c}\text { net capital } \\
\text { inflows }\end{array}$ & $\begin{array}{c}\text { net bank } \\
\text { inflows }\end{array}$ & $\begin{array}{c}\text { gross non- } \\
\text { resident inflows }\end{array}$ & $\begin{array}{c}\text { gross resident } \\
\text { inflows }\end{array}$ & EMP \\
\hline dlog(VIX) & -0.002 & 0.001 & $-0.010^{* * *}$ & $0.012^{* *}$ & $-0.039^{* *}$ \\
dlog(VIX)_NETEXP & $(0.003)$ & $(0.002)$ & $(0.003)$ & $(0.004)$ & $(0.016)$ \\
& 0.069 & -0.022 & 0.028 & 0.032 & 0.293 \\
NETEXP & $(0.043)$ & $(0.037)$ & $(0.023)$ & $(0.049)$ & $(0.170)$ \\
& 0.077 & 0.046 & 0.014 & $0.063^{* *}$ & $0.206^{* *}$ \\
d(i*) & $(0.053)$ & $(0.028)$ & $(0.049)$ & $(0.025)$ & $(0.080)$ \\
& 0.005 & -0.000 & $0.005^{*}$ & -0.002 & $-0.024^{* *}$ \\
d(i* $\left.{ }_{\text {sR }}\right)$ & $(0.004)$ & $(0.002)$ & $(0.003)$ & $(0.001)$ & $(0.009)$ \\
& -0.007 & -0.000 & $-0.008^{*}$ & 0.002 & -0.018 \\
\hline R_squared & $(0.005)$ & $(0.002)$ & $(0.004)$ & $(0.004)$ & $(0.025)$ \\
Adj. R_squared & 0.02 & 0.02 & 0.02 & 0.02 & 0.04 \\
Nobs & 0.01 & 0.01 & 0.01 & 0.01 & 0.03 \\
No.cross sections & 806 & 802 & 806 & 806 & 811 \\
Fixed effects & 21 & 21 & 21 & 21 & 20 \\
\hline
\end{tabular}

(C) Net exposure for Nonbanks

\begin{tabular}{|c|c|c|c|c|c|}
\hline & $\begin{array}{l}\text { net capital } \\
\text { inflows }\end{array}$ & $\begin{array}{l}\text { net bank } \\
\text { inflows }\end{array}$ & $\begin{array}{l}\text { gross non- } \\
\text { resident inflows }\end{array}$ & $\begin{array}{c}\text { gross resident } \\
\text { inflows }\end{array}$ & EMP \\
\hline \multirow[t]{2}{*}{$\overline{d \log (\mathrm{VIX})}$} & -0.002 & 0.001 & $-0.011^{* * *}$ & $0.013^{* * *}$ & $-0.043^{* *}$ \\
\hline & $(0.003)$ & $(0.002)$ & $(0.003)$ & $(0.004)$ & $(0.016)$ \\
\hline \multirow[t]{2}{*}{ dlog(VIX)_NETEXP ${ }_{N B, t-1}$} & $0.078^{* * *}$ & $0.024^{*}$ & $0.028^{* *}$ & $0.041^{*}$ & $0.217^{* * *}$ \\
\hline & (0.019) & $(0.013)$ & $(0.012)$ & $(0.022)$ & $(0.062)$ \\
\hline \multirow[t]{2}{*}{$\mathrm{NETEXP}_{\mathrm{NB}, \mathrm{t}-1}$} & -0.000 & 0.000 & 0.024 & -0.034 & 0.024 \\
\hline & (0.039) & $(0.013)$ & $(0.027)$ & $(0.034)$ & $(0.097)$ \\
\hline \multirow[t]{2}{*}{$d\left(i^{*}\right)$} & 0.005 & -0.000 & $0.005^{*}$ & -0.002 & $-0.024^{* * *}$ \\
\hline & $(0.004)$ & $(0.002)$ & $(0.002)$ & $(0.001)$ & $(0.008)$ \\
\hline \multirow[t]{2}{*}{$\mathrm{d}\left(\mathrm{i}^{*}{ }_{\mathrm{SR}}\right)$} & -0.007 & 0.000 & $-0.008 *$ & 0.003 & -0.020 \\
\hline & $(0.006)$ & $(0.002)$ & $(0.004)$ & $(0.004)$ & $(0.025)$ \\
\hline R_squared & 0.02 & 0.00 & 0.02 & 0.02 & 0.04 \\
\hline Adj. R_squared & 0.01 & -0.00 & 0.01 & 0.01 & 0.03 \\
\hline Nobs & 806 & 802 & 806 & 806 & 811 \\
\hline No.cross sections & 21 & 21 & 21 & 21 & 20 \\
\hline Fixed effects & Yes & Yes & Yes & Yes & Yes \\
\hline
\end{tabular}

Note: The regressions follow of those in Table 2 in the text. The sample countries include only EM countries. 
Table A8. Panel Regression Excluding the United States, 2002Q1-2017Q4

(a) Net exposure for total financial institutions

\begin{tabular}{|c|c|c|c|c|c|}
\hline & $\begin{array}{l}\text { net capital } \\
\text { inflows }\end{array}$ & $\begin{array}{l}\text { net bank } \\
\text { inflows }\end{array}$ & $\begin{array}{l}\text { gross non- } \\
\text { resident inflows }\end{array}$ & $\begin{array}{c}\text { gross resident } \\
\text { inflows }\end{array}$ & EMP \\
\hline \multirow[t]{2}{*}{$\operatorname{dlog}(\mathrm{VIX})$} & $-0.004^{*}$ & 0.001 & $-0.010 * * *$ & $0.009 * *$ & $-0.044^{* * *}$ \\
\hline & $(0.003)$ & $(0.002)$ & $(0.003)$ & (0.004) & $(0.014)$ \\
\hline \multirow[t]{2}{*}{$\operatorname{dlog}(\mathrm{VIX}) \_$NETEXP $\mathrm{FC,t-1}$} & $0.068^{*}$ & -0.013 & $0.041^{* *}$ & 0.011 & $0.287^{* *}$ \\
\hline & $(0.035)$ & $(0.035)$ & (0.019) & $(0.046)$ & $(0.123)$ \\
\hline \multirow[t]{2}{*}{ NETEXP $P_{F C, t-1}$} & 0.070 & 0.032 & 0.013 & $0.059^{* *}$ & $0.178^{* *}$ \\
\hline & $(0.047)$ & $(0.025)$ & $(0.045)$ & $(0.024)$ & $(0.079)$ \\
\hline \multirow[t]{2}{*}{$d\left(i^{*}\right)$} & 0.005 & -0.000 & $0.005^{*}$ & -0.002 & $-0.023^{* *}$ \\
\hline & $(0.004)$ & $(0.002)$ & $(0.003)$ & $(0.001)$ & $(0.009)$ \\
\hline \multirow[t]{2}{*}{$d\left(i^{*}{ }_{S R}\right)$} & -0.006 & -0.001 & $-0.007 *$ & 0.002 & -0.020 \\
\hline & $(0.005)$ & $(0.002)$ & $(0.003)$ & $(0.004)$ & $(0.022)$ \\
\hline R_squared & 0.02 & 0.01 & 0.02 & 0.02 & 0.04 \\
\hline Adj. R_squared & 0.01 & 0.00 & 0.01 & 0.01 & 0.03 \\
\hline Nobs & 927 & 923 & 927 & 927 & 932 \\
\hline No.cross sections & 23 & 23 & 23 & 23 & 22 \\
\hline Fixed effects & Yes & Yes & Yes & Yes & Yes \\
\hline
\end{tabular}

(b) Net exposure for banks

\begin{tabular}{lccccc}
\hline & $\begin{array}{c}\text { net capital } \\
\text { inflows }\end{array}$ & $\begin{array}{c}\text { net bank } \\
\text { inflows }\end{array}$ & $\begin{array}{c}\text { gross non- } \\
\text { resident inflows }\end{array}$ & $\begin{array}{c}\text { gross resident } \\
\text { inflows }\end{array}$ & EMP \\
\hline dlog(VIX) & -0.003 & 0.001 & $-0.009^{* * *}$ & $0.010^{* *}$ & $-0.037^{* *}$ \\
dlog(VIX)_NETEXP & $(0.003)$ & $(0.002)$ & $(0.003)$ & $(0.004)$ & $(0.014)$ \\
& 0.062 & -0.020 & $0.041^{*}$ & 0.009 & $0.315^{*}$ \\
NETEXP & $(0.041)$ & $(0.035)$ & $(0.023)$ & $(0.049)$ & $(0.157)$ \\
& 0.071 & 0.038 & 0.007 & $0.064^{* * *}$ & $0.176^{* *}$ \\
d(i*) & $(0.045)$ & $(0.024)$ & $(0.042)$ & $(0.021)$ & $(0.068)$ \\
& 0.005 & -0.000 & $0.005^{*}$ & -0.002 & $-0.023^{* *}$ \\
d(i* $\left.{ }_{\text {sR }}\right)$ & $(0.004)$ & $(0.002)$ & $(0.003)$ & $(0.001)$ & $(0.009)$ \\
& -0.006 & -0.001 & $-0.007^{*}$ & 0.002 & -0.019 \\
\hline R_squared & $(0.005)$ & $(0.002)$ & $(0.003)$ & $(0.004)$ & $(0.022)$ \\
Adj. R_squared & 0.02 & 0.02 & 0.02 & 0.02 & 0.04 \\
Nobs & 0.02 & 0.01 & 0.01 & 0.01 & 0.03 \\
No.cross sections & 927 & 923 & 927 & 927 & 932 \\
Fixed effects & 23 & 23 & 23 & 23 & 22 \\
& Yes & Yes & Yes & Yes & Yes \\
\hline
\end{tabular}

(C) Net exposure for Nonbanks

\begin{tabular}{|c|c|c|c|c|c|}
\hline & $\begin{array}{l}\text { net capital } \\
\text { inflows }\end{array}$ & $\begin{array}{l}\text { net bank } \\
\text { inflows }\end{array}$ & $\begin{array}{l}\text { gross non- } \\
\text { resident inflows }\end{array}$ & $\begin{array}{l}\text { gross resident } \\
\text { inflows }\end{array}$ & EMP \\
\hline \multirow[t]{2}{*}{ dlog(VIX) } & -0.004 & 0.001 & $-0.010 * * *$ & $0.010^{* *}$ & $-0.043^{* * *}$ \\
\hline & $(0.003)$ & $(0.002)$ & $(0.003)$ & (0.004) & $(0.015)$ \\
\hline \multirow{2}{*}{$\operatorname{dlog}(\mathrm{VIX}) \_N E T E X P_{\mathrm{NB}, \mathrm{t}-1}$} & $0.051^{* *}$ & $0.021^{* *}$ & $0.022^{*}$ & 0.019 & $0.176^{* * *}$ \\
\hline & $(0.020)$ & (0.009) & $(0.012)$ & $(0.018)$ & $(0.059)$ \\
\hline \multirow[t]{2}{*}{$\mathrm{NETEXP}_{\mathrm{NB}, \mathrm{t}-1}$} & -0.001 & -0.001 & 0.018 & -0.030 & 0.013 \\
\hline & $(0.037)$ & $(0.013)$ & $(0.026)$ & $(0.032)$ & $(0.095)$ \\
\hline \multirow[t]{2}{*}{$d\left(i^{*}\right)$} & 0.005 & -0.000 & $0.005^{* *}$ & -0.002 & $-0.024 * * *$ \\
\hline & $(0.004)$ & $(0.002)$ & $(0.002)$ & $(0.001)$ & $(0.008)$ \\
\hline \multirow[t]{2}{*}{$d\left(i_{S R}^{*}\right)$} & -0.006 & -0.001 & $-0.007^{* *}$ & 0.002 & -0.021 \\
\hline & $(0.005)$ & $(0.002)$ & $(0.004)$ & $(0.004)$ & $(0.022)$ \\
\hline R_squared & 0.01 & 0.00 & 0.02 & 0.01 & 0.03 \\
\hline Adj. R_squared & 0.01 & -0.00 & 0.01 & 0.01 & 0.03 \\
\hline Nobs & 927 & 923 & 927 & 927 & 932 \\
\hline No.cross sections & 23 & 23 & 23 & 23 & 22 \\
\hline Fixed effects & Yes & Yes & Yes & Yes & Yes \\
\hline
\end{tabular}

Note: The regressions follow of those in Table 2 in the text. The sample countries include all except the United States. 